Article

\title{
Geochemistry and Geochronology of Ophiolitic Rocks from the Dongco and Lanong Areas, Tibet: Insights into the Evolution History of the Bangong-Nujiang Tethys Ocean
}

\author{
Peng Yang 1,2@ , Qiangtai Huang ${ }^{1,3, *}$, Renjie Zhou ${ }^{2}$, Argyrios Kapsiotis ${ }^{1,3}$, Bin Xia ${ }^{1,3} \oplus^{\circ}$, \\ Zhanli Ren ${ }^{4}$, Zhourong Cai ${ }^{1,3}{ }^{-0}$, Xingxin $\mathrm{Lu}^{1,3}$ and Chiyu Cheng ${ }^{1,3}$ \\ 1 Guangdong Provincial Key Laboratory of Marine Resources and Coastal Engineering, Key Laboratory of \\ Offshore Oil Exploration and Development of Guangdong Higher Education Institutes, School of Marine \\ Sciences, Sun Yat-Sen University, Guangzhou 510006, China \\ 2 School of Earth and Environmental Sciences, The University of Queensland, Brisbane, QLD 4072, Australia \\ 3 Southern Marine Science and Engineering Guangdong Laboratory, Zhuhai 519082, China \\ 4 State Key Laboratory of Continental Dynamics, Department of Geology, Northwest University, \\ Xi'an 710069, China \\ * Correspondence: huangqt7@mail.sysu.edu.cn
}

Received: 30 June 2019; Accepted: 26 July 2019; Published: 30 July 2019

\begin{abstract}
The Bangong-Nujiang Suture Zone (BNSZ) in central Tibet hosts a series of dismembered Jurassic ophiolites that are widely considered as remnants of the vanished Meso-Tethys Ocean. In this study we present new compositional, isotopic, and geochronological data from anorthosites and gabbros of the Dongco and Lanong ophiolites in order to test several hypotheses about the nature of subduction in the Bangong-Nujiang Tethys Ocean (BNTO) during the Mesozoic era. Uranium- $\mathrm{Pb}$ dating of magmatic zircons separated from the Dongco anorthosites yielded an (average) age of $169.0 \pm$ 3.7 Ma. Zircons separated from the Lanong anorthosites and gabbros yielded U-Pb ages of $166.8 \pm 0.9 \mathrm{Ma}$ and $167.3 \pm 1.1 \mathrm{Ma}$, respectively. Zircons separated from the Dongco and Lanong anorthosites have positive $\varepsilon_{\mathrm{Hf}}(\mathrm{t})$ values (5.62-15.94 and 10.37-14.95, respectively). The Dongco anorthosites have moderate initial ${ }^{87} \mathrm{Sr} /{ }^{86} \mathrm{Sr}(0.703477-0.704144)$ and high $\varepsilon_{\mathrm{Nd}}(\mathrm{t})(+6.50$ to +7.91$)$. The Lanong anorthosites have high $\left({ }^{87} \mathrm{Sr} /{ }^{86} \mathrm{Sr}\right)_{i}(0.706058-0.712952)$ and $\varepsilon_{\mathrm{Nd}}(\mathrm{t})$ in the range of -1.56 to +2.02. Furthermore, the Lanong gabbros have high $\left({ }^{87} \mathrm{Sr} /{ }^{86} \mathrm{Sr}\right)_{i}(0.705826-0.706613)$ and $\varepsilon_{\mathrm{Nd}}(\mathrm{t})$ in the range of -0.79 to +4.20 . Most gabbros from Dongco and a few gabbros from Lanong show normal mid-ocean ridge basalt (N-MORB)-like primitive mantle (PM)-normalized multi-element patterns. In contrast, most gabbros from Lanong show U-shaped chondrite-normalized rare earth element (REE) profiles. The investigated gabbros are characterized by wide ranges of $\delta \mathrm{Eu}\left\{(\mathrm{Eu})_{\mathrm{N}} /\left[(\mathrm{Sm})_{\mathrm{N}}{ }^{*}(\mathrm{Gd})_{\mathrm{N}}\right]^{1 / 2}\right\}$ values (0.83-2.53), indicating that some of them are cumulative rocks. The trace element contents of all anorthosite samples imply that their composition was controlled by cumulative processes. The geochemical and isotopic compositions of the non-cumulative gabbros from Dongco ( $\delta \mathrm{Eu}$ : 0.95-1.04) and Lanong ( $\delta \mathrm{Eu}: 0.83-1.03$ ) indicate that their parental melts were derived from melting of heterogeneously depleted, juvenile mantle reservoirs. These rocks have arc-related affinities, indicating that their mantle sources were influenced by minor inputs of subducted lithospheric components. Our preferred hypothesis for the origin of the non-cumulative gabbros from Dongco is that they were formed in a transient back-arc basin (BAB) setting in the middle-western segment of the BNTO, whereas our preferred scenario about the origin of the non-cumulative gabbros from Lanong is that they were generated in a forearc setting in the middle part of the BNTO. We conclude that both geotectonic settings were developed in response to the northward subduction of the BNTO during the Middle Jurassic.
\end{abstract}

Keywords: gabbros; ophiolites; geochemistry; U-Pb dating; Bangong-Nujiang Tethys; Tibet 


\section{Introduction and Rationale of the Study}

The interpretation of the on-land ophiolitic rock units as remnants of ancient oceanic crust and mantle has brought considerable interest to the investigation of ophiolitic assemblages in orogenic belts [1-4]. These "fossil" sections of oceanic lithosphere are indisputable recorders of first-order geological phenomena such as seafloor spreading, slab subduction, and oceanic lithosphere emplacement onto the continental margins [4-7]. These geological processes are generally considered as primary with respect to the mechanisms that are responsible for the igneous accretion, (ductile and brittle) deformation, and post-solidification alteration of the oceanic lithosphere [8]. In addition, the internal architecture and compositional signatures of ophiolites may provide key elements in deciphering the petrotectonic history of the ancient oceanic lithosphere from its birth to its demise [4,9-12].

Today, a significant part of our knowledge about the oceanic lithosphere comes from the study of the ophiolitic assemblages cropping out along the Alpine-Himalayan orogenic belt [13]. The Alpine-Himalayan mountain belt is a world-class orogenic system that was formed due to the northward drifting of some Gondwana-derived plates and their collision with the southern margin of the Eurasian plate. This process led to the terminal closure of the Tethys Ocean in the interval between the Late Triassic and the Late Cenozoic [14,15]. The investigation of the Alpine-Himalayan ophiolites has provided the geological community with numerous details about the dynamic break-up of the northern Gondwana and the accretion of the southern Eurasia $[14,16]$.

The Tibetan Plateau, in the eastern segment of the Alpine-Himalayan orogenic belt, is a result of the collisional orogeny along the convergent boundary between the Indo-Australian and Eurasian lithospheric plates. From north to south, the Tibetan Plateau is composed of the Songpan-Ganzi, Qiangtang, Lhasa, and Himalayan terranes all separated from one another by extensive suture zones [17-19]. The Bangong-Nujiang Suture Zone (BNSZ) separates the Qiangtang terrane to the north from the Lhasa terrane to the south [20], hosting a number of supra-subduction-zone (SSZ)-type ophiolites that are considered as remnants of the vanished Meso-Tethys Ocean [21,22].

Although some detailed studies about the origin of the BNSZ ophiolites have been carried out during the last decades, ophiolites from the western and middle parts of the BNSZ are still under-documented. This limits our knowledge of the evolution history of the Bangong-Nujiang Tethys Ocean (BNTO; [23-26]). Several key issues such as configuration, opening, subduction, and closure of the BNTO have yet to be understood $[18,19,27,28]$. In particular, the geotectonic setting of the BNSZ ophiolites has been the subject of many frontline studies and remains a hotly debated issue among geoscientists, many of whom passionately defend hypotheses about the origin of these ophiolites [19,29].

In this paper, field and petrographic observations as well as geochemical and $\mathrm{Sr}-\mathrm{Nd}$ isotopic data are used to provide constraints on the origin of the Dongco and Lanong ophiolites. We also report new $\mathrm{U}-\mathrm{Pb}$ geochronological and $\mathrm{Lu}-\mathrm{Hf}$ isotopic data for zircons separated from some mafic rocks of these ophiolites. Integration of our compositional and geochronological data may help in the resolution of the puzzling petrogenetic evolution of the BNSZ ophiolites during the Mesozoic.

\section{Geological Background}

The Tibetan Plateau was formed due to tectonic amalgamation of continental blocks that rifted from the northern passive margin of the Gondwana supercontinent in the Paleozoic and Mesozoic, moved northward, and accreted to southern active continental margin of Eurasia (Figure 1a; $[19,26,27,30]$ ). In the Tibetan area, these continental blocks are separated by four suture zones; namely (from north to south), the A'nemaqin Kunlun Suture Zone (AKSZ), the Jinsha Suture Zone (JSSZ), the Bangong-Nujiang Suture Zone (BNSZ), and the Yarlung Zangbo Suture Zone (YZSZ; Figure 1b; [17]). 


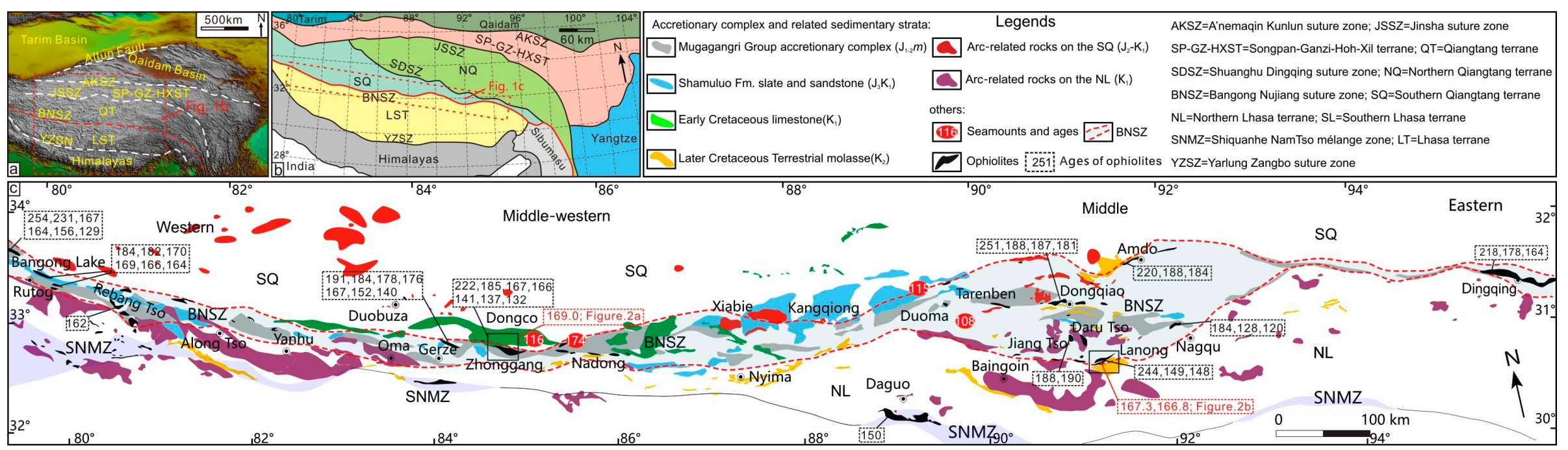

Figure 1. (a) Topography map of the Tibetan Plateau (digital elevation model data), showing major sutures by white dashed lines [17]. The Bangong-Nujiang Suture Zone (BNSZ) is shown by the red dashed line. (b) Tectonic outline of the Tibetan Plateau showing the location of the BNSZ (red line) [19]. (c) Generalized geological map of the BNSZ showing the occurrence of ophiolites $[19,27,30]$. The ages of the ophiolites, seamounts, and arc-related rocks are also shown. Compilation of data is from Table S1 in Supplementary Materials and references therein. 
Among these, the Jurassic-Cretaceous BNSZ is a more than 2000-km-long and 10-50-km-wide, $\mathrm{E}-\mathrm{W}$ trending tectonic zone separating the Lhasa block to the south from the southern Qiangtang block to the north (Figure 1a-c; [19]). The northern part of the BNSZ is characterized by NE striking, sinistral strike-slip faults, whereas the southern part of the BNSZ is characterized by the dominance of NW trending, right lateral strike-slip faults. An important feature of the middle segment of the BNSZ is that it hosts a $\sim 100-\mathrm{km}$-long and $\sim 50-\mathrm{km}$-wide, pre-Mesozoic crystalline formation known as the Amdo basement (Figure 1c). This Paleozoic formation is generally composed of orthogneisses and metasediments.

Scattered along the BNSZ is a discontinuous belt of ophiolites that are tectonically juxtaposed against a series of accretionary prism complexes in the northern margin of the Lhasa terrane. Ophiolites within the BNSZ occur as discontinuous lensoidal bodies within a mélange-type lithological matrix. These ophiolites represent remnants of the Meso-Tethys Ocean that was subducted under the Qiangtang terrane during the Jurassic-Cretaceous. The oceanic outcrops of the BNSZ include the western ophiolites (e.g., Bangong Lake, Rutog, Rebang Tso), the middle-western ophiolites (e.g., Gerze, Dongco, Kangqiong), the middle ophiolites (e.g., Dongqiao, Amdo, Lanong, and Naqu), and the eastern ophiolites (e.g., Dingqing, Figure 1c) [31,32]. Here, we focus on the Dongco and Lanong ophiolites, cropping out in the middle-western and middle segments of the BNSZ, respectively (Figure 1c).

\subsection{The Dongco Ophiolite}

The intensively dismembered Dongco ophiolite is located in the eastern Gerze County (Figure 2a; $[33,34])$. The approximate thickness of the reconstructed ophiolitic section is $\sim 18 \mathrm{~km}$. The Dongco ophiolite crops out as a series of imbricate thrust nappes emplaced onto the northern margin of the Lhasa terrane. It includes serpentinized mantle peridotites, massive and layered gabbros, pillow basalts, and minor radiolarian cherts $[35,36]$. Amphibolite blocks occur within a serpentinite matrix mélange covering the central part of the Dongco ophiolite area. Cretaceous volcaniclastic rocks overlap both sides of the ophiolitic unit [37]. The Dongco ophiolite is unconformably overlain by Cretaceous limestones and is in tectonic contact with Jurassic strata $[25,27,33,35]$.

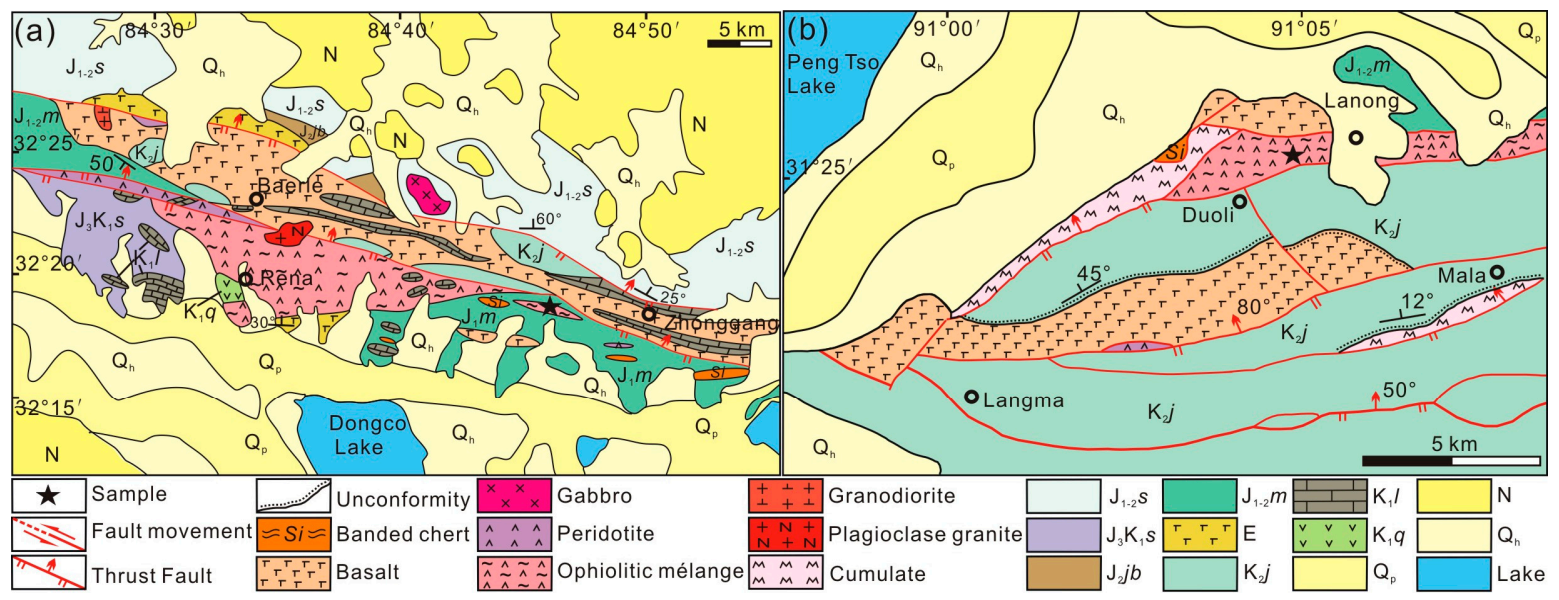

Figure 2. Geological maps of the Dongco (a; modified after [27]) and Lanong ophiolites (b; modified after [28]). The black asterisks indicate the sample locations. Note: $\mathrm{K}_{2} j$-Jingzhushan Formation, $\mathrm{K}_{1}$ l-Langshan Formation, $\mathrm{K}_{1} q$-Qushenla Formation, $\mathrm{J}_{3} \mathrm{~K}_{1} s$-Shamuluo formation, $\mathrm{J}_{2-3}$ l—Lagongtang Formation; $\mathrm{J}_{2} j b$-Jiebuqu Formation, $\mathrm{J}_{1-2} m$-Magagangri Group.

Whole-rock K-Ar age and bulk-rock $\mathrm{Rb}-\mathrm{Sr}$ age data from the basaltic tuffs of the Qushenla Formation suggest that the igneous accretion of the Dongco oceanic crust started before the Early Cretaceous [38]. However, geochronological data indicate that oceanic spreading in the Dongco marginal basin most likely occurred in the Early Jurassic ( $191 \pm 22 \mathrm{Ma})$ and was followed by subduction that lasted from the Late Jurassic $(152.3 \pm 3.60 \mathrm{Ma})$ to the Early Cretaceous (140 $\pm 4.07 \mathrm{Ma})$ [39]. 
Moreover, the Meso-Tethys Ocean in the Dongco area most likely continued existing until the final stages of subduction in the Early Cretaceous [33].

Based on the compositional signatures and ${ }^{39} \mathrm{Ar} /{ }^{40} \mathrm{Ar}$ geochronological data of amphibolite blocks from the ophiolitic mélange, it was suggested that the Dongco ophiolite was formed in a transient back-arc basin (BAB) in the Middle Jurassic [34]. In addition, zircons from the Dongco gabbros yielded an average $\mathrm{U}-\mathrm{Pb}$ age of $167 \pm 2 \mathrm{Ma}$, indicating that the gabbros were derived from a BAB setting linked to an Early-Middle Jurassic intra-oceanic subduction zone [27]. Furthermore, zircons separated from the Dongco gabbros yielded an average $\mathrm{U}-\mathrm{Pb}$ age of $222.5 \pm 4.8 \mathrm{Ma}$, suggesting a Late Triassic intra-oceanic subduction zone as the geotectonic setting of the Dongco ophiolite [40].

\subsection{The Lanong Ophiolite}

The Lanong ophiolite crops out to the southeast of Peng Tso Lake in the Baingoin County. It is 20 $\mathrm{km}$ long and has a width of up to $7 \mathrm{~km}$ (Figure $2 \mathrm{~b}$ ). It occurs as a series of tectonic slices of oceanic rocks in a nearly W-E direction [28,38]. It represents an incomplete ophiolitic section that appears tectonically dismembered and variably altered. It includes tectonically separate lenses of mantle peridotites, mafic rocks, and radiolarian cherts [41]. The Jurassic-Early Cretaceous Qixinong flyschoidal sedimentary formation and the Upper Cretaceous Jingzhushan Formation exhibit fault contacts with the Lanong ophiolitic fragments [28]. In addition, an angular unconformity occasionally observed between the Lanong ophiolite and the Late Cretaceous Jingzhushan Formation testifies that ophiolite formation most likely happened before the Late Cretaceous [28].

Previous investigations have suggested that the Lanong ophiolite was probably formed in a BAB geotectonic setting during the Jurassic $[38,41]$. However, the geochemical signatures of mafic lavas and dykes show that the Lanong ophiolitic rocks most likely represent lithospheric vestiges with island arc-type signatures [22]. In contrast, an investigation by the Xizang Geological Survey Institute (2003) showed that the Lanong ophiolite might have been generated at a mid-ocean ridge (MOR) geotectonic environment [41]. Furthermore, it has been proposed that the Lanong ophiolite was formed in a forearc regime linked to the southward subduction of the BNTO beneath the Lhasa terrane during the Middle Triassic-Early Cretaceous [28].

\section{Petrographic Delineation}

\subsection{Ophiolitic Rocks from Dongco}

Our macroscopic observations show that the Dongco ophiolite is composed of mantle peridotites, mafic cumulates (mainly gabbros), mafic sills and (anorthosite) dykes, and basalts (Figure 3a-f). All these lithologies were found in the form of deformed exotic blocks within a highly sheared serpentinite-rich matrix (Figure 3c).

Mantle peridotite blocks have a dark green to brownish color (Figure 3a). They range in petrographic terms from lherzolite to harzburgite with minor dunite and are moderately serpentinized (Figure $3 b$ ). Peridotites may be pervasively mylonitized, showing schistosity due to ductile shearing. They are in tectonic contact with the Jurassic Mugagangri Group flysch $\left(\mathrm{J}_{1-2} m\right)$ and are unconformably overlain by the limestones of the Cretaceous Langshan Formation ( $\mathrm{K}_{1} l$; Figure 3a). Cumulate gabbro boulders commonly have a grey color and are slightly altered (Figure $3 \mathrm{~d}$ ). When observed in hand specimens, they show a typical holocrystalline texture made up of plagioclase crystals filling the gaps between clinopyroxene grains. We note that gabbro in the blocks is occasionally intruded by whitish anorthosite veins with a thickness of less than 10-15 cm (Figure 3e). Basalt blocks have a light brown to dim gray color, showing a pervasive isotropic, fine granular to aphanitic fabric, and a typical pillow-like structure (Figure 3f). Pillow basalts occasionally show boudins and "crack out" structures.

In this study, we focused on a number of anorthosite samples $(N=7)$ taken from the southeastern part of the Dongco ophiolite. We also focused on 10 gabbro samples previously studied by [27]. 
Anorthosites are mainly composed of plagioclase (>90 modal\%) and a much smaller amount of clinopyroxene ( $<10$ modal\%), showing typical granular textures (Figure $3 \mathrm{~g}, \mathrm{~h}$ ). Plagioclase form subhedral to euhedral grains that are generally shorter than $3 \mathrm{~mm}$. They have perfect cleavages and display polysynthetic twinning (Figure $3 \mathrm{~g}, \mathrm{~h}$ ). Pyroxenes form subhedral grains $(<0.6 \mathrm{~mm})$, filling the space between plagioclase crystals (Figure 3h). Plagioclase in anorthosites has been affected by saussuritization. Clinopyroxene has undergone uralitization. Occasionally, tiny $(<0.1 \mathrm{~mm})$ opaque metallic phases were observed as minor accessory minerals in the investigated anorthosite samples.
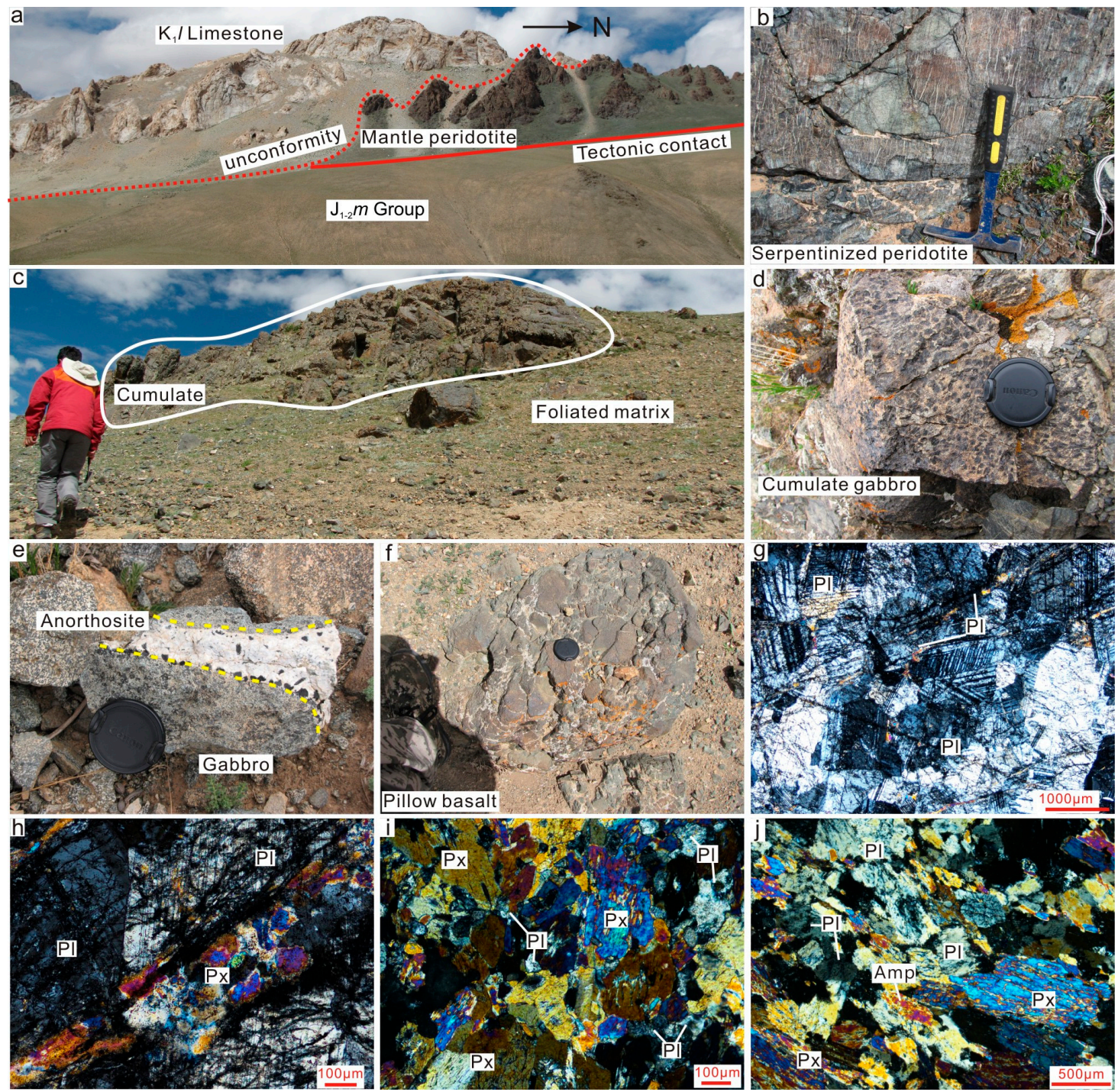

Figure 3. Field photographs $(\mathbf{a}-\mathbf{f})$ and micrographs $(\mathbf{g}-\mathbf{j})$ of the Dongco ophiolites. (a) Mantle peridotites unconformably overlain by the $\mathrm{K}_{1} l$ limestones and in tectonic contact with the $\mathrm{J}_{1-2} \mathrm{~m}$ formation; (b) serpentinized peridotite; (c) a block of cumulate rocks within a foliated mélange matrix; (d) cumulate gabbro; (e) massive gabbro intruded by anorthosite; (f) pillow basalt; (g,h) photomicrographs of anorthosite; $(\mathbf{i}, \mathbf{j})$ photomicrographs of gabbro. Note: (a) The mantle peridotite is about $500 \mathrm{~m}$ long, the red solid line corresponds to tectonic contact, and the red dashed line represents an angular unconformity; (c) the white solid line represents boundary of cumulate and foliated matrix; (d-f) diameter of the camera lens cap is $67 \mathrm{~mm}$; (e) the yellow dashed marks the contacts between gabbro and anorthosite. Abbreviations: Pl, plagioclase; Px, pyroxene; Amp, amphibole.

Gabbros are mainly composed of plagioclase (45-50 modal\%), clinopyroxene (45-50 modal\%), and accessory amounts of metallic minerals (i.e., Fe-Ti oxides; Figure 3i,j). Gabbros show granular and 
occasionally equigranular texture. These rocks contain anhedral to subhedral crystals of plagioclase $(\leq 0.4 \mathrm{~mm})$ and clinopyroxene $(\leq 0.3 \mathrm{~mm})$. Plagioclase and clinopyroxene show weak undulatory extinction and are often cut by a network of randomly oriented intragranular brittle fractures. Plagioclase in gabbros has undergone saussuritization (Figure 3i,j), whereas gabbroic clinopyroxene may be pseudomorphically replaced by tremolite (Figure 3j).

\subsection{Ophiolitic Rocks from Lanong}

Our field work has documented the occurrence of mantle peridotites, anorthosites, dolerites, gabbros, basalts, and radiolarian chert blocks (Figure $4 \mathrm{a}-\mathrm{g}$ ) within a serpentinite-rich matrix. This appears analogous to that cropping out in the Dongco area.
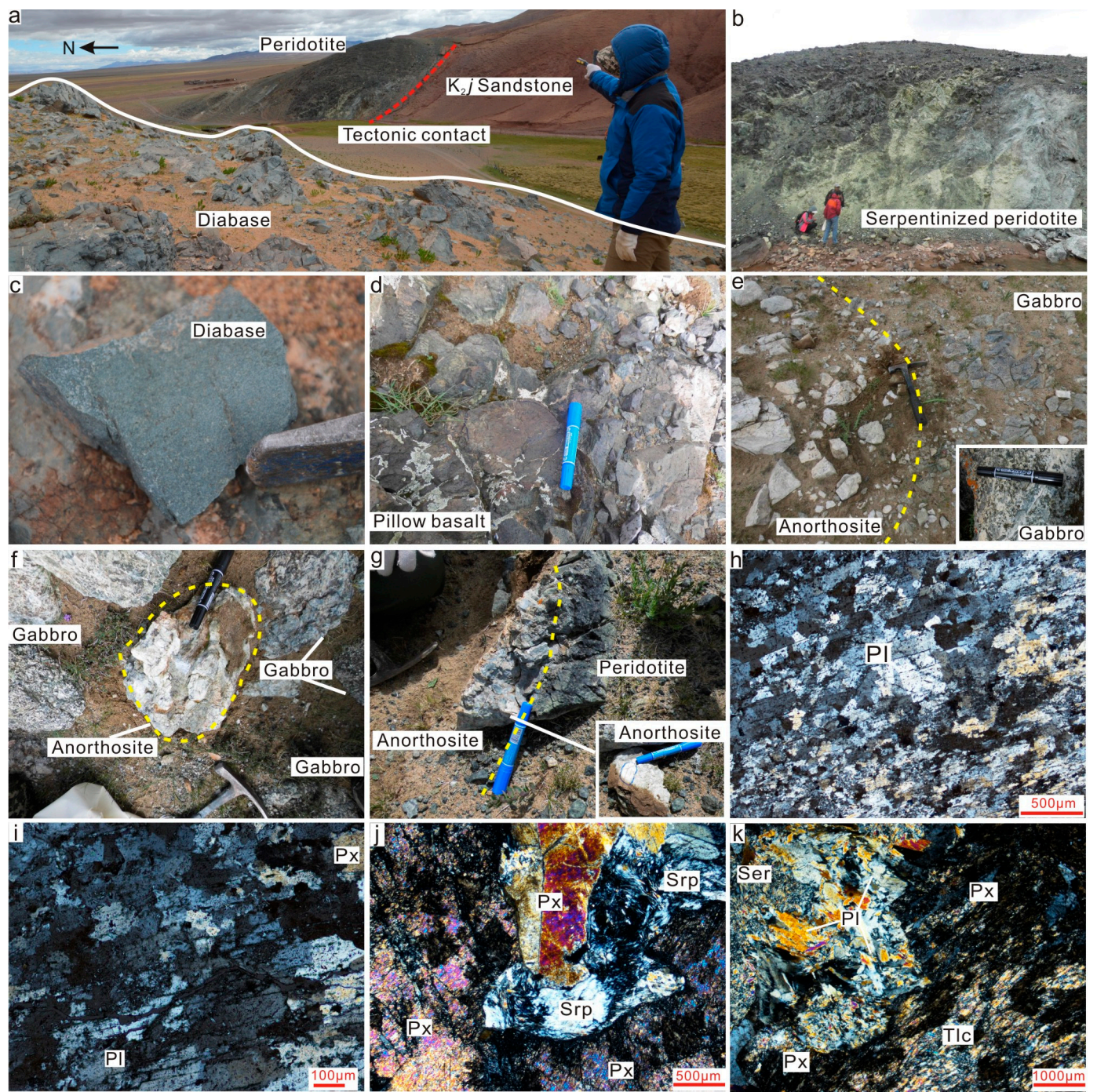

Figure 4. Field photos (a-g) and photomicrographs (h-k) of the Lanong ophiolites. (a) Dolerite and peridotite are in tectonic contact with the Late Cretaceous Jingzhushan Formation $\left(\mathrm{K}_{2} j\right)$; (b) serpentinized peridotite; (c) dolerite; (d) pillow basalt; (e,f) anorthosite and gabbro; (g) anorthosite and peridotite; $(\mathbf{h}, \mathbf{i})$ photomicrographs of anorthosite; $(\mathbf{j}, \mathrm{k})$ photomicrographs of gabbro. Note: (a) The red dashed line corresponds to tectonic contact between peridotite and sandstone; (c) geological hammer appears about $2 \mathrm{~cm}$ in this figure; $(\mathbf{d}-\mathbf{g})$ the marker pens are about $142 \mathrm{~mm}$, and the yellow dashed line in $(\mathbf{e}-\mathbf{g})$ marks the contacts between anorthosite-gabbro (e,f) and anorthosite-peridotite (g). Abbreviations: $\mathrm{Pl}$-plagioclase; Px—pyroxene; Srp—serpentine; Ser—sericite; Tlc—talcum. 
A fault tectonic contact separates mantle peridotite from the purplish-red sandstones of the Late Cretaceous Jingzhushan Formation $\left(\mathrm{K}_{2} j\right.$; Figure $\left.4 \mathrm{a}\right)$. Mantle peridotites exhibit a dark green color and are intensely sheared and almost completely altered (Figure 4b). Intrusive contacts between gabbro and anorthosite (Figure 4e,f) as well as between anorthosite and peridotite (Figure 4g) were observed. The contact between gabbro and anorthosite may occasionally be marked by deposits of carbonate minerals. Furthermore, crevices in pillow basalts are occasionally filled with carbonate minerals (mainly calcite; Figure 4d).

Herein, we focused on a number of specimens collected from various anorthosite intrusions and their gabbro hosts ( $N=2$ and 15, respectively) from the northeastern part of the Lanong ophiolite.

Anorthosites are mainly composed of plagioclase ( $>95$ modal\%), containing a small percentage of clinopyroxene ( $<5$ modal\%; Figure $4 \mathrm{~h}, \mathrm{i})$. Gabbros are mainly composed of plagioclase $(\sim 45-50$ modal \%), clinopyroxene ( 45-50 modal\%), and accessory amounts of metallic minerals (Figure 4j,k). Both lithologies show typical unequigranular textures. Pyroxene and plagioclase grains in gabbros and anorthosites exhibit unhedral shapes with crystal sizes ranging between 0.1 and $3 \mathrm{~mm}$. Small $(\leq 50 \mu \mathrm{m})$ anidiomorphic to idiomorphic crystals of accessory ilmenite and magnetite occasionally occupy any spaces between much larger plagioclase and clinopyroxene grains in gabbros. The serpentinization and talc-alteration of clinopyroxene and the saussurization of plagioclase (Figure 4j) indicate that gabbros underwent low-mid temperature post-solidification alteration.

\section{Analytical Methods}

Whole-rock analyses of major element oxides were carried out using a PANalytical Axios-Advanced (Axios PW4400, PANalytical B.V., Almelo, the Netherlands) X-ray fluorescence (XRF) spectrometer at the State Key Laboratory of Ore Deposit Geochemistry, Institute of Geochemistry, Chinese Academy of Sciences (CAS), Guiyang. Bulk-rock trace elements, including the lanthanides, were measured at the Nanjing Focus Technology Co. Ltd. (Nanjing, China) using an Agilent Technologies 7700x quadrupole inductively coupled plasma-mass spectrometer (ICP-MS; Hachioji, Tokyo, Japan).

Zircons were separated by conventional heavy-liquid and isodynamic magnetic methods at the Langfang Regional Geological Survey, Hebei Province, China. Zircons separated from the Dongco anorthosite (XDC08) were dated by secondary ion mass spectrometry (SIMS) (IMS1280-HR system, CAMECA, Gennevilliers, France) at the State Key Laboratory of Isotope Geochemistry, Guangzhou Institute of Geochemistry (CAS). Zircons separated from the Lanong ophiolitic anorthosite (16XLN03-1) and gabbro (16XLN07-1) were dated by laser ablation (LA)-ICP-MS technique at the Nanjing Focus Technology Co. Ltd. using an Analyte Excite Excimer laser-ablation system (193 nm Excimer Laser Ablation System, Photon Machines, Bozeman, MT, USA) and an Agilent Technologies 7700x quadrupole ICP-MS (Hachioji, Tokyo, Japan).

High precision $\mathrm{Sr}-\mathrm{Nd}$ isotopic measurements were carried out at the Nanjing Focus Technology Co. Ltd. using a using Agilent Technologies 7700x quadrupole ICP-MS (Hachioji, Tokyo, Japan).

All tables are presented in the Supplementary Materials File 1 (Tables S1-S6). Ages of ophiolitic fragments from Bangong-Nujiang Suture Zone (BNSZ), central Tibetan Plateau are given in Table $\mathrm{S} 1$. Bulk-rock and standards geochemical data are given in Table S2. Zircon U-Pb geochronological data are presented in Table S3. The Hf isotopic compositions of zircons are provided in Table S4. Whole-rock Sr-Nd isotopic data are presented in Table S5. Ages of arc-related rocks from the Northern Lhase terrane and Southern Qiangtang terrane, Tibetan Plateau are given in Table S6. A more detailed description of all the analytical procedures is provided in the Supplementary Materials File 2.

\section{Analytical Results}

\subsection{Geochemistry}

Anorthosites and gabbros from the Dongco and Lanong ophiolites and standards were analyzed for their major-element oxide and trace element contents (Table S2). 
The Dongco anorthosites have varying concentrations of $\mathrm{SiO}_{2}(47.05-47.79 \mathrm{wt} \%), \mathrm{Al}_{2} \mathrm{O}_{3}$ (30.01-31.32 wt \%), $\mathrm{Na}_{2} \mathrm{O}(2.23-2.37 \mathrm{wt} \%)$, and $\mathrm{K}_{2} \mathrm{O}(0.08-0.14 \mathrm{wt} \%)$. The Lanong anorthosites have slightly lower concentrations of $\mathrm{SiO}_{2}(40.40-42.20 \mathrm{wt} \%), \mathrm{Al}_{2} \mathrm{O}_{3}(23.74-24.40 \mathrm{wt} \%), \mathrm{Na}_{2} \mathrm{O}$ (0.01-0.07 wt \%), and $\mathrm{K}_{2} \mathrm{O}(0.01-0.16 \mathrm{wt} \%)$ than the Dongco anorthosites. The $\mathrm{Mg} \#[100 \times \mathrm{Mg} / \mathrm{Mg}+$ $\left.\mathrm{Fe}^{2+}\right)$ ] values of the Dongco anorthosites range between 45.17 to 67.21. In addition, the Mg\# values of the Lanong anorthosites vary from 76.61 and 83.48. The loss on ignition (LOI) values of the Dongco anorthosites range from $1.64 \mathrm{wt} \%$ to $2.06 \mathrm{wt} \%$. The LOI values of the Lanong anorthosites vary between $5.05 \mathrm{wt} \%$ and $6.39 \mathrm{wt} \%$.

The Dongco gabbros have similar $\mathrm{SiO}_{2}$ (46.14-50.99 wt \%), $\mathrm{Al}_{2} \mathrm{O}_{3}$ (15.43-26.71 wt \%), $\mathrm{MgO}\left(5.30-11.71\right.$ wt \%), $\mathrm{Na}_{2} \mathrm{O}(0.64-2.31 \mathrm{wt} \%)$ and $\mathrm{K}_{2} \mathrm{O}(0.02-0.30 \mathrm{wt} \%)$ contents to those of the Lanong gabbros $\left(\mathrm{SiO}_{2}=42.69-51.46 \mathrm{wt} \%, \mathrm{Al}_{2} \mathrm{O}_{3}=13.96-20.23 \mathrm{wt} \%, \mathrm{MgO}=5.72-11.20 \mathrm{wt} \%\right.$, $\left.\mathrm{Na}_{2} \mathrm{O}=0.11-3.38 \mathrm{wt} \%, \mathrm{~K}_{2} \mathrm{O}=0.02-1.46 \mathrm{wt} \%\right)$. The Mg\# values of the Dongco gabbros vary between 64.50 and 89.87, whereas the Mg\# values of the Lanong gabbros range from 58.54 to 79.19 . The Dongco gabbros have LOI values ranging from $0.94 \mathrm{wt} \%$ and $2.87 \mathrm{wt} \%$, whereas the Lanong gabbros have LOI values varying between $2.17 \mathrm{wt} \%$ and $5.01 \mathrm{wt} \%$.

The majority of the Dongco gabbros and a number of gabbros from the Lanong area show PM-normalized multi-element patterns characterized by strong enrichments in large-ion lithophile element (LILE; i.e., $\mathrm{Ba}, \mathrm{U}, \mathrm{Pb}$, and $\mathrm{Sr}$ ) and depletions in high-field-strength element (HFSE; i.e., $\mathrm{Nb}, \mathrm{Ta}, \mathrm{Ti}, \mathrm{Zr}$, and Hf; Figure $5 \mathrm{a}, \mathrm{b})$. In addition, gabbros from the Dongco area show light rare earth element (LREE)-depleted chondrite-normalized rare earth element (REE) patterns (Figure 5c). In contrast, most gabbros from the Lanong area show flat to U-shaped chondrite-normalized REE profiles (Figure $5 \mathrm{~d}$ ). We note that the Dongco and Lanong gabbros are characterized by wide ranges of $\delta \mathrm{Eu}\left\{(\mathrm{Eu})_{\mathrm{N}} /\left[(\mathrm{Sm})_{\mathrm{N}}{ }^{*}(\mathrm{Gd})_{\mathrm{N}}\right]^{1 / 2}\right\}$ values $(0.95-2.53$ and $0.83-1.65$, respectively). Such wide ranges of $\delta \mathrm{Eu}$ values imply the involvement of plagioclase fractionation $(<1)$ or accumulation $(>1)$ processes in the genesis of the investigated gabbros.

Anorthosites from both study areas show varying PM-normalized trace element patterns (Figure 5a,b). The Dongco anorthosites show obviously right-sloping chondrite-normalized REE patterns (Figure 5c) and the Lanong anorthosites show light right-sloping chondrite-normalized REE patterns (Figure $5 \mathrm{~d}$ ). The Dongco anorthosites display strong positive Eu anomalies $(\delta \mathrm{Eu}=3.66-6.60$; Table S2, Figure $5 c)$ similar to the Lanong anorthosites $(\delta \mathrm{Eu}=3.29-4.65$; Table S2, Figure $5 \mathrm{~d})$. Both Dongco and Lanong anorthosites are generally characterized by an enrichment in the LREE (Figure $5 c, d$ ).

\subsection{Uranium-Pb Dating of Zircons}

Zircon crystals were separated from two anorthosite samples (XDC08, 16XLN03-1) and a single gabbro sample (16XLN07-1). The morphological characteristics and internal microtextures of zircons (Figure 6) were studied using optical and scanning electron microscopy prior to geochronological dating and isotopic analyses. 

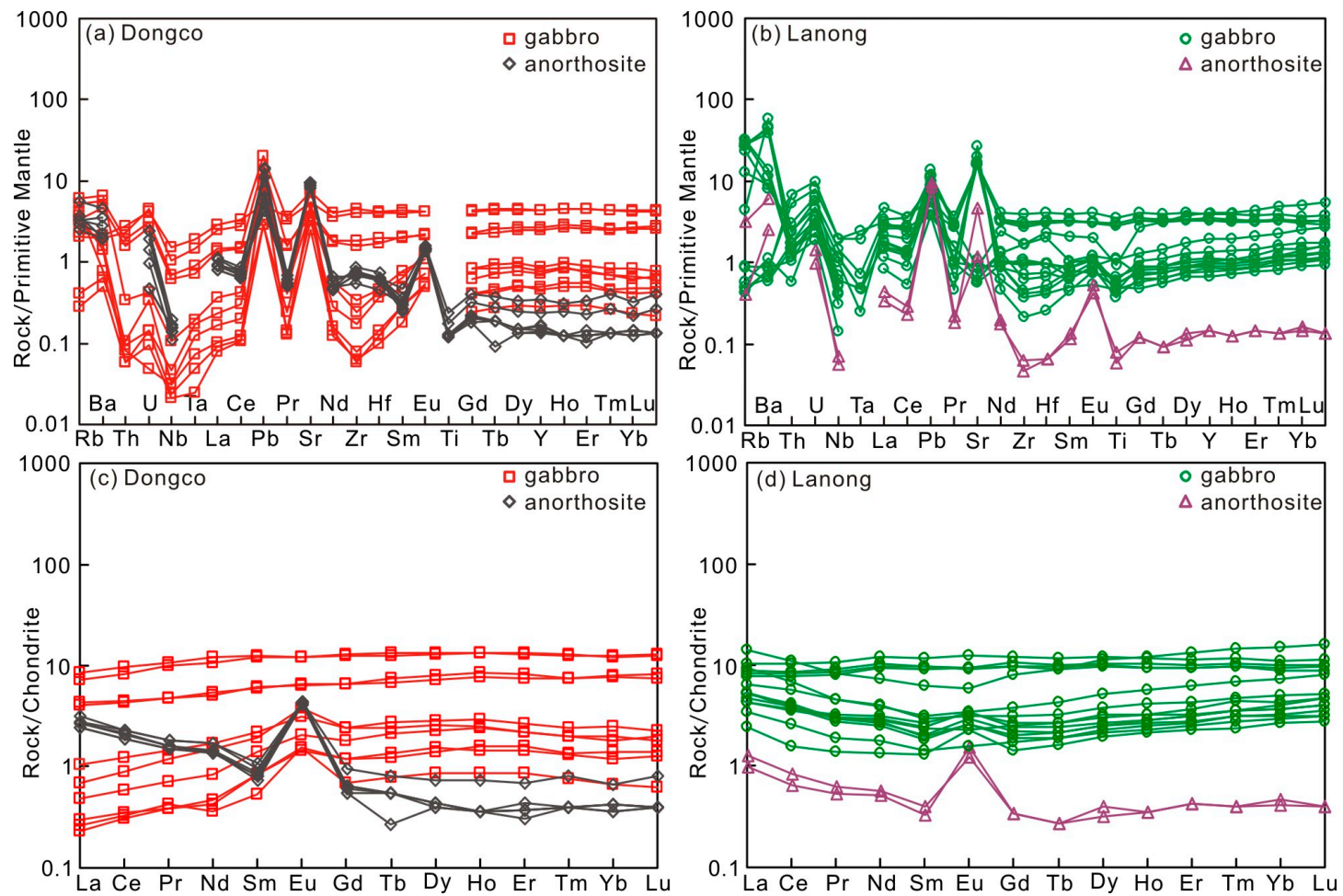

Figure 5. (a,b) Primitive mantle (PM)-normalized trace element patterns of gabbros and anorthosites from the Dongco and Lanon ophiolites. (c,d) Chondrite-normalized rare earth element (REE) patterns of gabbros and anorthosites from the Dongco and Lanon ophiolites. Twelve of the Dongco gabbro samples are from [27]. Primitive mantle- and chondrite-normalizing values are from [42].

The zircon grains separated from the Dongco anorthosite (XDC08) have ovoid shapes and vary from $50 \mu \mathrm{m}$ to $150 \mu \mathrm{m}$ in size (Figure 6a). In cathodoluminescence (CL) images, they display oscillatory to sector zoning (Figure 6a). They have high Th/U (0.41-1.38; Table S3) indicating a magmatic origin [43]. Twenty-five analyses of zircons from this sample form a relatively tight cluster in the U-Pb concordia diagram, yielding a weighted mean ${ }^{206} \mathrm{~Pb} /{ }^{238} \mathrm{U}$ age of $169.0 \pm 3.7 \mathrm{Ma}$ (mean square of weighted deviates, MSWD $=0.28$; Figure 7a,b).

The zircon grains that were recovered from the Lanong anorthosite (16XLN03-1) are short prismatic, ranging between $30 \mu \mathrm{m}$ and $150 \mu \mathrm{m}$ in size (Figure 6b). In CL images, they display narrow-spaced oscillatory zoning parallel to their external crystal faces. A few zircons with bright domains along crystal boundaries were also observed (Figure 6b). These domains are most likely due to interaction of zircons with post-magmatic fluids. All zircons from the Lanong anorthosite have Th/U ranging from 0.33 to 1.38 (Table S3). Fifteen spot analyses of zircons yielded a mean average ${ }^{206} \mathrm{~Pb} /{ }^{238} \mathrm{U}$ age of $166.8 \pm 0.9 \mathrm{Ma}(\mathrm{MSWD}=0.76$; Figure 7c,d).

The zircon crystals separated from a gabbro sample from Lanong (16XLN07-1) are unhedral to subhedral, commonly short prismatic to ovoid. They range between $60 \mu \mathrm{m}$ and $200 \mu \mathrm{m}$ in size. In addition, they display broad-spaced oscillatory zoning (Figure $6 \mathrm{c}$ ) and have Th/U ranging from 0.52 to 4.43 (Table S3). Fifteen spot analyses of zircons yielded a weighted mean ${ }^{206} \mathrm{~Pb} /{ }^{238} \mathrm{U}$ age of $167.3 \pm 1.1 \mathrm{Ma}(\mathrm{MSWD}=1.40$; Figure 7e,f).

We note that all the investigated zircon grains are free of visible mineral inclusions and overgrowths. In addition, they show no sign of magmatic resorption and have no inherited cores. Moreover, our data indicate that there is no correlation between $\mathrm{U}-\mathrm{Pb}$ age and crystal morphology or internal texture of the examined zircons. In addition, the existence of a single zircon age population in each rock specimen indicates that the investigated zircons were crystallized from the rock-forming melts and are unlikely of xenocrystic origin $[13,44]$. 


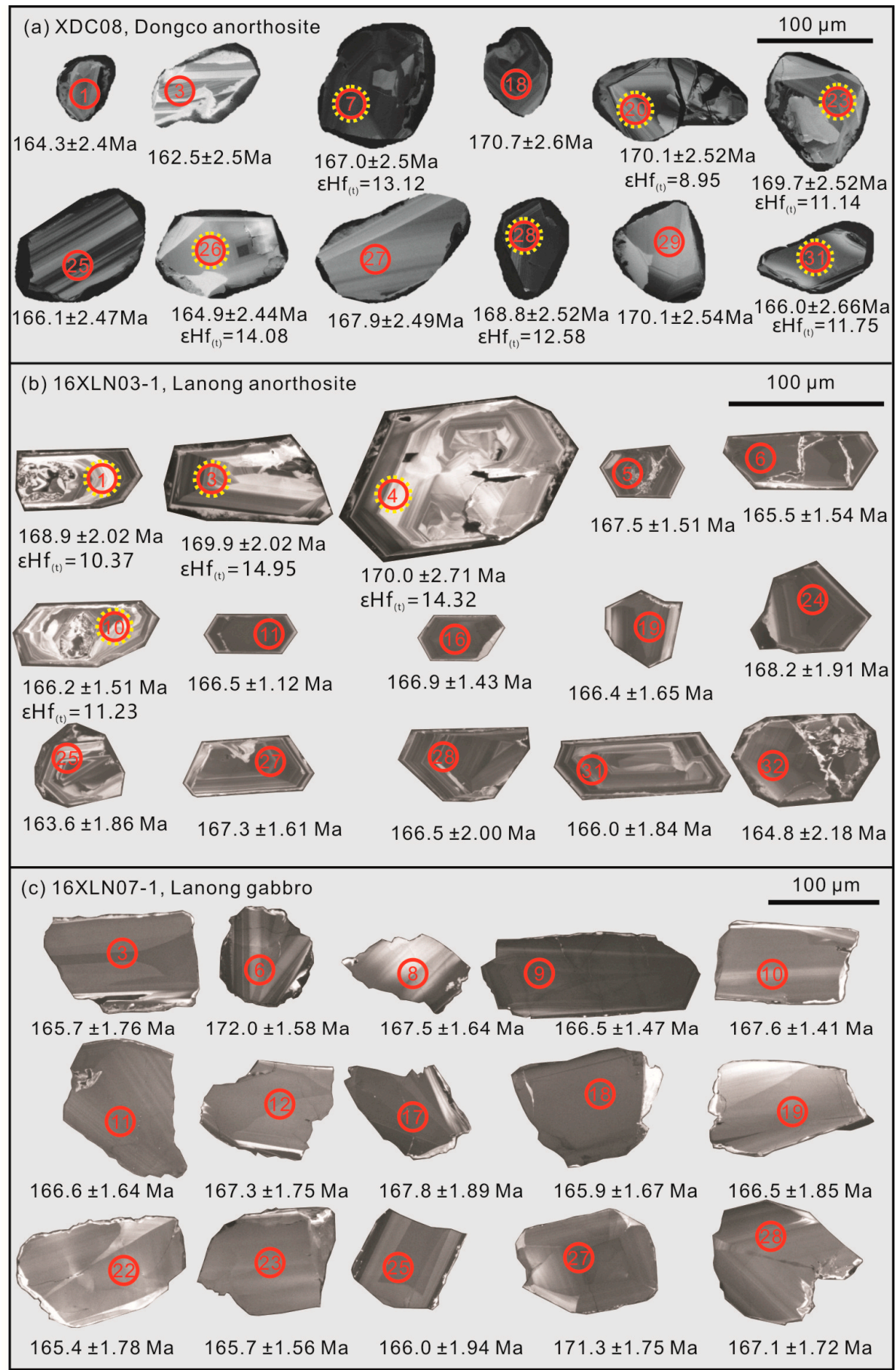

Figure 6. Cathodoluminescence images showing the internal micro-textures of the zircon grains we separated from the investigated rocks from the Dongco and Lanong ophiolites. Solid red circles indicate the sites of $\mathrm{U}-\mathrm{Pb}$ geochronological dating and yellow dotted circles indicate the sites of in situ $\mathrm{Lu}-\mathrm{Hf}$ isotopic analysis. (a) Sample XDC08: Anorthosite from the Dongco ophiolite; (b) sample 16XLN03-1: Anorthosite from the Lanong ophiolite; (c) sample 16XLN07-1: Gabbro from the Lanong ophiolite. 

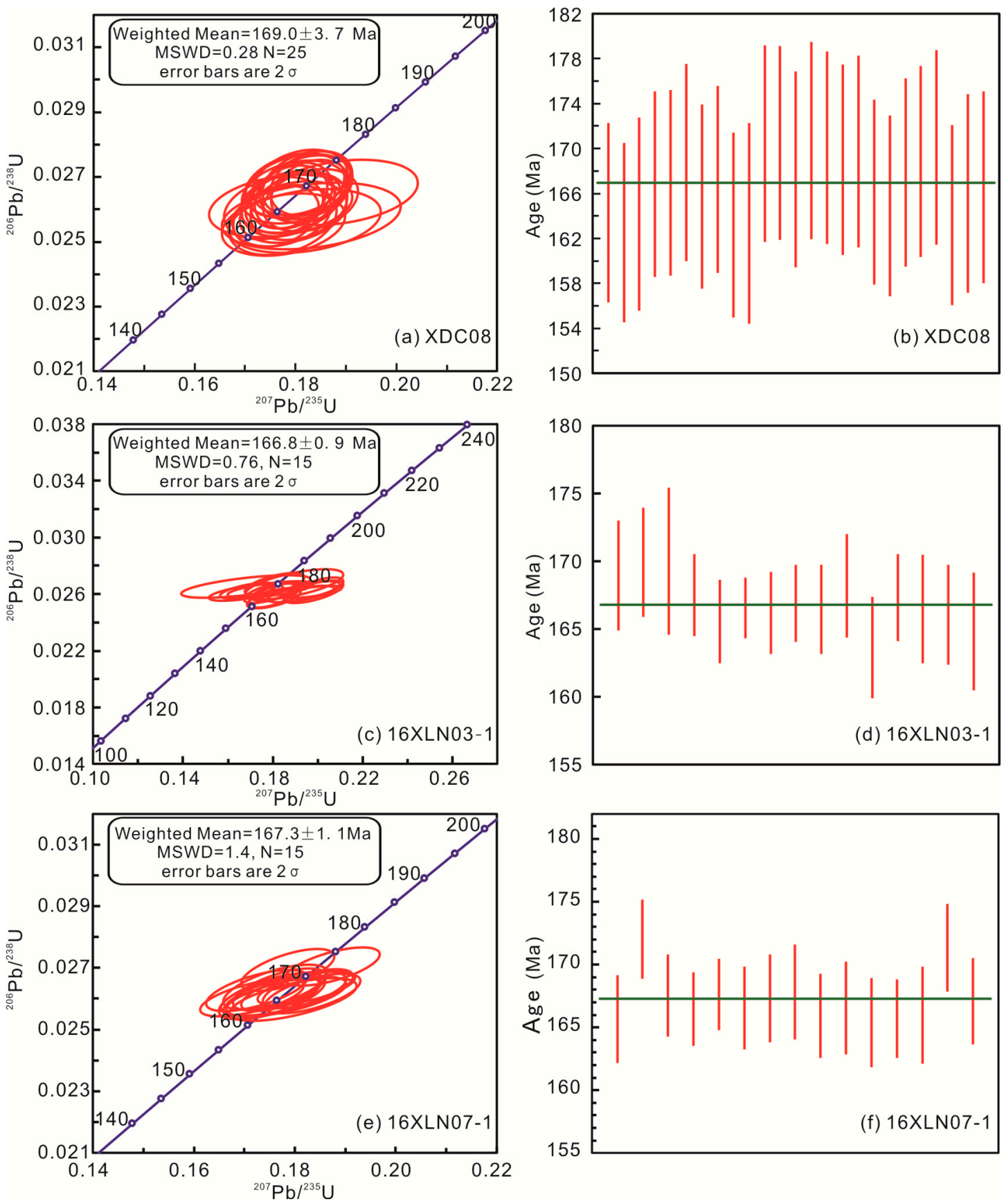

Figure 7. Zircon $\mathrm{U}-\mathrm{Pb}$ concordia curves and average plots of the analyzed zircon grains separated from the investigated rocks of the Dongco and Lanong ophiolites. (a,b) Sample XDC08: Anorthosite, Dongco ophiolite; (c,d) sample 16XLN03-1: Anorthosite, Lanong ophiolite; (e,f) sample 16XLN07-1: Gabbro, Lanong ophiolite.

\subsection{Hafnium Isotopic Composition of Zircons}

Lutetium-Hf isotope analyses of zircons were carried out on the same spots previously analyzed for $\mathrm{U}-\mathrm{Pb}$ isotopes. Sixteen zircon grains separated from the Dongco anorthosite sample XDC08 and four zircon grains separated from the Lanong anorthosite sample 16XLN03-1 were selected for Hf isotope analysis (Table S4).

Zircons recovered from the Dongco anorthosite have initial ${ }^{176} \mathrm{Hf} /{ }^{177} \mathrm{Hf}$ ratios ranging from 0.282840 to 0.283127 , and $\varepsilon_{\mathrm{Hf}}(\mathrm{t})$ values varying between +5.62 and +15.94 (Table S4). Their single-stage Hf model ages $\left(\mathrm{T}_{\mathrm{DM} 1}\right)$ are in the range of $180.3-637.0 \mathrm{Ma}$ and their two-stage $\mathrm{Hf}$ model ages $\left(\mathrm{T}_{\mathrm{DM} 2}\right)$ are 
in the range of 189.7-853.5 Ma. Zircons separated from the Lanong anorthosite (16XLN03-1) have initial ${ }^{176} \mathrm{Hf} /{ }^{177} \mathrm{Hf}$ ratios varying from 0.282868 to $0.283105,{ }^{176} \mathrm{Yb} /{ }^{177} \mathrm{Hf}$ ratios ranging between 0.134067 and 0.184966 , and $\varepsilon_{\mathrm{Hf}}(\mathrm{t})$ values in the range of +10.37 to +14.95 . Their $\mathrm{T}_{\mathrm{DM} 1}$ vary from $231.8 \mathrm{Ma}$ to $449.2 \mathrm{Ma}$ and their $\mathrm{T}_{\mathrm{DM} 2}$ range between $258.5 \mathrm{Ma}$ and 552.1 Ma.

The range of the $\varepsilon_{\mathrm{Hf}}(\mathrm{t})$ values of the zircons separated from the Dongco anorthosite differs from that of the $\varepsilon_{\mathrm{Hf}}(\mathrm{t})$ values of the zircons separated from the Lanong anorthosite (Table S4). This could be interpreted as an indication of isotopic heterogeneity of the anorthosite-forming melts [13]. When plotted against the U-Pb ages of zircons, their $\varepsilon_{\mathrm{Hf}}(\mathrm{t})$ values do not spread at all, but they fall between the DM- and chondrite uniform reservoir (CHUR)-control lines (Figure 8a).
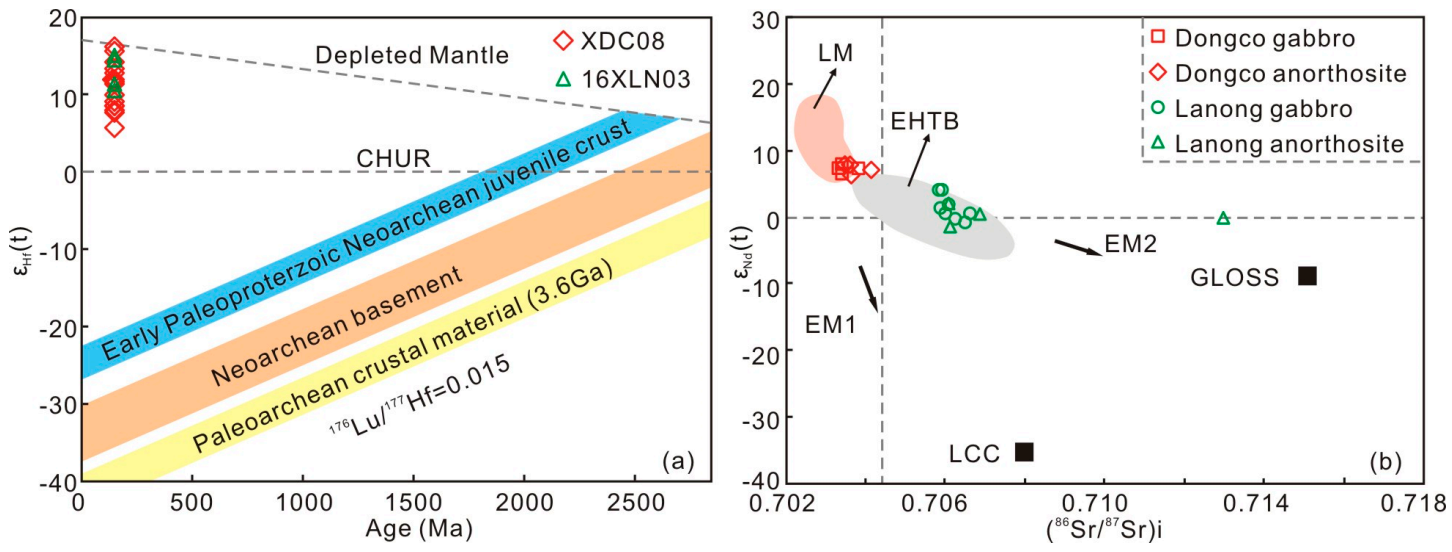

Figure 8. (a) Variations of $\mathrm{U}-\mathrm{Pb}$ ages versus $\varepsilon \mathrm{Hf}(t)$ of zircons separated from the Dongco and Lanong ophiolites. Abbreviations: CHUR, chondritic uniform reservoir. (b) Plots of $\left({ }^{87} \mathrm{Sr} /{ }^{86} \mathrm{Sr}\right)_{i}-\varepsilon_{\mathrm{Nd}}(\mathrm{t})$ [28]. The fields of LM (lithospheric mantle) are represented by peridotite xenoliths from Cenozoic basalts in Shanwang [45] and Beiyan [46]. Data for EHTB (Emeishan high-Ti basalts) are from [47,48].

\subsection{Strontium-Nd Isotopic Systematics}

The Lanong anorthosites have initial ${ }^{87} \mathrm{Sr} /{ }^{86} \mathrm{Sr}$ varying between 0.706058 and 0.712952 , and initial ${ }^{143} \mathrm{Nd} /{ }^{144} \mathrm{Nd}$ ranging from 0.512343 to 0.512527 . They also have $\varepsilon_{\mathrm{Nd}}(\mathrm{t})$ values in the range of -1.56 to +2.02 (Table S5). The Lanong gabbros have analogous ranges of $\left({ }^{87} \mathrm{Sr} /{ }^{86} \mathrm{Sr}\right)_{i}$ and $\left({ }^{143} \mathrm{Nd} /{ }^{144} \mathrm{Nd}\right)_{i}$ (0.705826-0.706613 and 0.512382-0.512638, respectively) with those of the Lanong anorthosites. However, the $\varepsilon_{\mathrm{Nd}}(\mathrm{t})$ values of the Lanong gabbros vary more $(-0.79$ to +4.20$)$ compared to those of the Lanong anorthosites (Table S5).

The Dongco anorthosites have moderate $\left({ }^{87} \mathrm{Sr} /{ }^{86} \mathrm{Sr}\right){ }_{i}$ and high $\left({ }^{143} \mathrm{Nd} /{ }^{144} \mathrm{Nd}\right){ }_{i}(0.703477-0.704144$ and 0.512753-0.512826, respectively; Table S5). Furthermore, they have high $\varepsilon_{\mathrm{Nd}}(\mathrm{t})$ values (+6.50 to +7.91), consistent with those of the Dongco gabbros (+6.62 to +8.09) [27].

In the $\varepsilon_{\mathrm{Nd}}(\mathrm{t})-\left({ }^{87} \mathrm{Sr} /{ }^{86} \mathrm{Sr}\right)_{i}$ binary plot, the ophiolitic rocks from Dongco straddle the boundaries between the compositional fields of the lithospheric mantle (LM) and the Emeishan high-Ti basalts (EHTB; Figure 8b). With one exception, all ophiolitic rocks from Lanong plot within the field corresponding to the isotopic composition of the EHTB (Figure 8b). The exception (16XLN03-4) plots away from the rest mafic rock samples most likely owing to post-magmatic alteration.

\section{Discussion}

\subsection{Potential Effects of Post-Solidification Alteration, Melt Fractionation, and Crustal Contamination}

Our petrographic observations indicate that the investigated ophiolitic rocks from both study areas were affected to some extent by post-solidification alteration. This is consistent with the wide variations in their LOI values (0.94-6.39 wt \% collectively). Therefore, only those elements that were not significantly affected by post-magmatic processes were used to infer conclusions about the petrogenesis of the Dongco and Lanong ophiolites. These include major-element oxides such 
as $\mathrm{P}_{2} \mathrm{O}_{5}, \mathrm{MnO}$, and $\mathrm{TiO}_{2}$, and some incompatible trace elements such as $\mathrm{Hf}, \mathrm{Th}, \mathrm{Y}, \mathrm{Ta}, \mathrm{Nb}$, and the REE. The good correlations between these elements and the relatively immobile $\mathrm{Zr}$ imply that their concentrations were not disturbed by metamorphic or hydrothermal alteration processes (Figure S1 in Supplementary Materials) $[49,50]$.

All anorthosite samples from the Dongco ophiolite and Lanong ophiolite display chondrite-normalized REE patterns that are characterized by marked positive Eu anomalies (Figure $5 c, d$ ). This implies massive accumulation of plagioclase consistent with our petrographic observations. Furthermore, all anorthosites show strong enrichments in the HREE indicating that their compositions were significantly controlled by cumulus processes (i.e., early removal of plagioclase). Similarly, a number of gabbros from the Dongco (11DC-1, 11DC-3, 11DC-4, 11DC-7, 11DC-8, 11DC-39) and Lanong (16XLN02-4, 16XLN02-5, 16XLN07-1, 16XLN07-4, 16XLN07-5, 16XLN09-3) ophiolites have probably been affected by cumulus processes given their positive Eu anomalies (1.30-2.53 and 1.23-1.95, respectively). By the reasoning in the foregoing discussion, it is inferred that the compositions of anorthosites and several gabbros do not represent original liquid compositions and, thus, they will be omitted from the following interpretations.

In contrast, the compositions of the rest gabbro samples from the Dongco (11DC-6, 11DC-16, 11DC-37, and 11DC-38) and Lanong (16XLN02-1, 16XLN02-2, 16XLN02-3, 16XLN09-4, 16XLN09-5, 16XBLN02-1, 16XBLN02-2, 16XBLN02-3, and 16XBLN02-4) areas with $\delta$ Eu ranging between 0.95-1.04 and $0.83-1.03$, respectively, may be analogous to liquid compositions. These non-cumulative gabbros have relatively high Mg\# values (Dongco: 64.50-70.25; Lanong: 65.15-79.19), implying that they were formed by melts that were not significantly affected by fractional crystallization during their ascent to shallow lithospheric levels. Therefore, it can be assumed that the non-cumulative gabbros were derived from melts that were sufficiently primitive to reflect the geochemical and isotopic signatures of their mantle sources.

We note that the Sr-Nd isotopic compositions of the Dongco gabbros are analogous to that of the LM. In addition, the Sr-Nd isotopic compositions of the Lanong gabbros are analogous to that of the EHTB. These observations rule out the possibility that the parental melts of the investigated gabbros were influenced by crustal contamination. This is also corroborated by the absence of a positive correlation between the $\mathrm{K}_{2} \mathrm{O}$ and $\mathrm{SiO}_{2}$ contents of the investigated gabbros [51]. In addition, crustal contamination would lead to high $\mathrm{Th} / \mathrm{Nd}$ [52]. However, the investigated mafic samples are characterized by low $\mathrm{Th} / \mathrm{Nd}$ (Dongco: 0.03-0.40, Lanong: 0.02-0.25).

Our assessment of the geochemical and isotopic compositions of the non-cumulative gabbros from the Dongco and Lanong areas is that they reflect the compositions of their parental magmas. Therefore, the largest part of the following discussion will be based on the geochemical and isotopic signatures of the investigated non-cumulative gabbros.

\subsection{Insights into the Origin of Anorthosites}

Anorthosites are important constituents of Archean mafic-ultramafic layered intrusions [53]. In contrast, anorthosites are only rarely reported from the crustal section of ophiolites [54]. Anorthosites in ophiolites typically occur as thin layers and small lensoidal bodies within the cumulate gabbro unit [55]. In general, they have been interpreted as plagioclase-rich cumulates produced by fractionating mafic magmas [54]. Nevertheless, the investigated anorthosites occur as intrusions within gabbros and peridotites. They do not display "topographic" intrusional boundaries, gradations in grain size, or internal modal layering as is typical for various igneous intrusions. In addition, they do not show any evidence of plagioclase growth on the walls of magma chambers or accumulation of plagioclase crystals due to gravitational sinking. Our field observations indicate that the Dongco and Lanong anorthosite veins represent fracture-filling structures within gabbros and peridotites. Furthermore, petrographic observations show that plagioclase grains in the investigated anorthosites display strain fabrics such as undulatory extinction and granulation around crystal boundaries (Figures $3 \mathrm{~g}$ and $4 \mathrm{~h}$ ). 
We, therefore, interpret the Dongco and Lanong anorthosite veins as late syn-kinematic intrusions that were emplaced into the oceanic lithosphere at semi-ductile to brittle conditions.

Even though the knowledge-base of the deformational history of the Dongco and Lanong ophiolites is not well established yet, the anorthosite intrusions they host may provide significant insights into a deformation stage that is inferred to be almost concurrent to the initiation of nappe formation. We conclude that the investigated anorthosite dykes represent subtle products of an intriguing phase of deformation-mineralization, which became active while oceanic magmatism was taking its "last gasps". We emphasize the lack of information about the post-ductile phase of deformation within a cooling lithospheric slab. Consequently, the thorough study of anorthosite intrusions may have significant implications for the post-ductile evolution of lithospheric slabs created in ridgecrest spreading [56].

\subsection{Petrogenesis of the Dongco Gabbros}

Several conflicting scenarios have been proposed to explain the enigmatic origin of the Dongco ophiolite. It has been interpreted as part of: (i) An Early Jurassic oceanic basin [35,36,39], (ii) an Early Cretaceous oceanic island [33], or (iii) a Mesozoic oceanic plateau [25,57]. It has also been viewed as formed in a Middle-Early Jurassic transient BAB [34] or a BAB in an intra-oceanic subduction system $[27,40]$.

In the $\mathrm{Th}-\mathrm{Nb} / 16-\mathrm{Hf} / 3$ tectonic discrimination diagram, the compositions of the non-cumulative gabbros from Dongco plot in the field of rocks with island arc tholeiitic (IAT) affinities (Figure 9a). In addition, on the $\mathrm{MnO} \times 10-\mathrm{TiO}_{2}-\mathrm{P}_{2} \mathrm{O}_{5} \times 10$ ternary diagram, the compositions of the non-cumulative gabbros from the Dongco area fall into the field of rocks with IAT and boninitic compositions (Figure 9a). Collectively, these gabbros show geochemical characteristics analogous to those of mafic rocks formed in an SSZ setting.

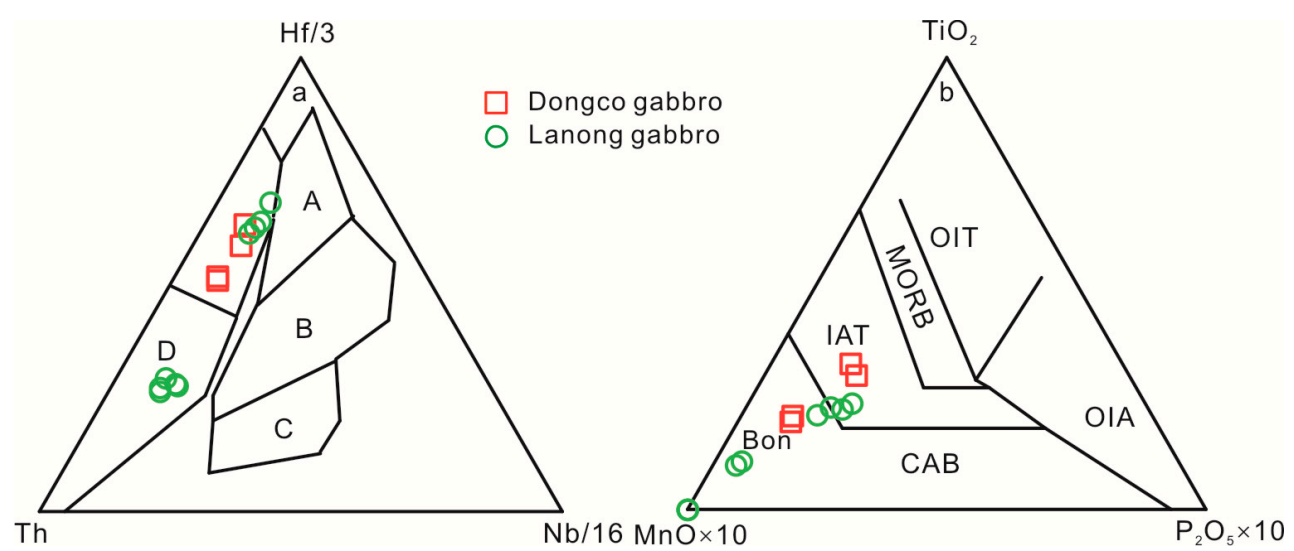

Figure 9. Ternary tectonic discrimination plots for the investigated non-cumulative gabbros from the Dongco and Lanong ophiolites. (a) Th-Nb-Hf diagram [50]; A: N-MORB, B: E-MORB, C: Within-plate alkali basalt (WPA), D: Island arc tholeiite basalt (IAT). (b) $\mathrm{MnO}-\mathrm{TiO}_{2}-\mathrm{P}_{2} \mathrm{O}_{5}$ [58]; OIT: Ocean island tholeiite or seamount tholeiite; OIA: Ocean island alkali basalt or seamount alkali basalt; CAB: Island arc calc-alkaline basalt; IAT: Island arc tholeiite; Bon: boninite.

Furthermore, on the $\mathrm{Th} / \mathrm{Yb}-\mathrm{Nb} / \mathrm{Yb}$ proxy diagram, the compositions of the Dongco gabbros plot above the MORB-OIB array, following a trend characterized by an apparent enrichment in Th (Figure 10a). This most likely indicates that the mantle source of their parental melts was affected, to some extent, by the input of crustal materials. Our geochemical data show that a small addition of subduction-related components in the mantle source of the non-cumulative gabbros from Dongco could sufficiently explain their enrichment in Th (Figure 10a). The majority of the non-cumulative gabbros from the Dongco area have SSZ-like affinities except for one gabbro sample that plots in the continental arc field (Figure 10a). We note that most of the non-cumulative gabbros from the Dongco ophiolite plot out of the compositional field of forarc basaltic (FAB) rocks from the Izu Bonin Mariana 
(IBM) arc system (Figure 10a). Collectively, these geochemical signatures could be interpreted as a result of gabbro formation in a developing arc basin. This is also supported by the PM-normalized multi-element patterns of the non-cumulative gabbros from Dongco showing negative anomalies in $\mathrm{Nb}$, just like those of tholeiitic magmas produced in arc-related settings [10]. Consequently, the question arises as to what was the exact geotectonic environment that was responsible for the formation of the investigated gabbros?
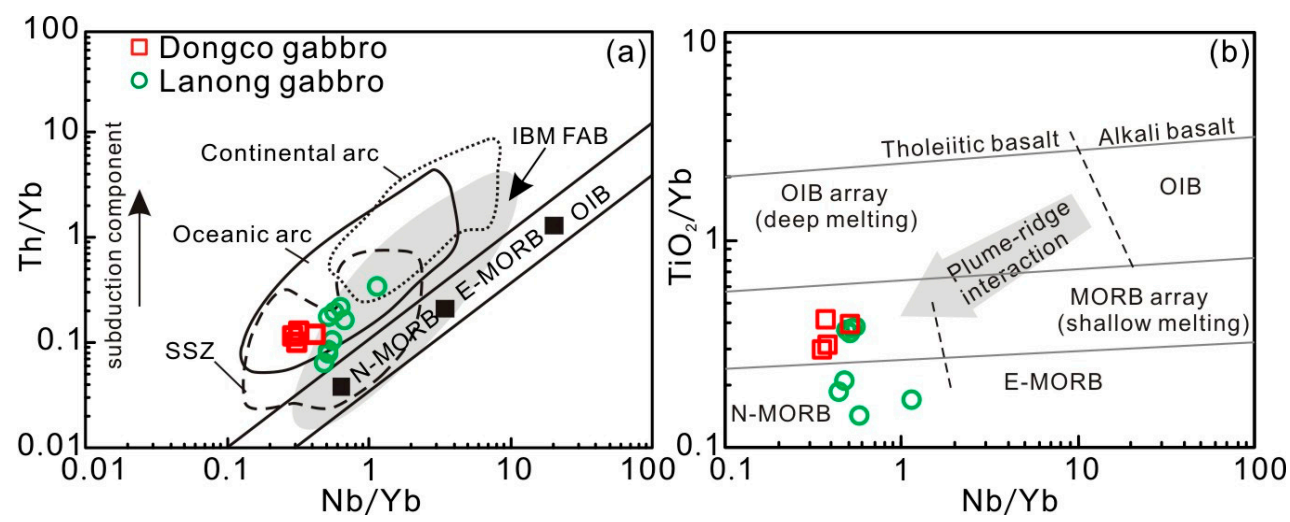

Figure 10. Tectonic discrimination diagrams for the investigated non-cumulative gabbros from the Dongco and Lanong ophiolites. (a) Plots of $\mathrm{Nb} / \mathrm{Yb}-\mathrm{Th} / \mathrm{Yb}$ [59]. Supra-subduction-zone types are from references [1,60-62]. (b) Plots of $\mathrm{Nb} / \mathrm{Yb}-\mathrm{TiO}_{2} / \mathrm{Yb}$ [59]. Abbreviations: IBM-Izu Bonin Mariana, FAB —-Fore arc basalt, MORB—Mid-ocean ridge basalt, OIB—Ocean island basalt.

The majority of the non-cumulative gabbros from the Dongco area have chondrite-normalized REE patterns analogous to those of typical MORB-type rocks. However, a couple of non-cumulative gabbros from Dongco have chondrite-normalized REE patterns that resemble those of E-MORB- and OIB-type rocks. Therefore, it can be postulated that the Dongco gabbros have a polygenetic origin. Moreover, the coexistence of mafic rocks with a wide range of geochemical affinities within the same ophiolite is quite unusual. Nevertheless, extensive compositional variation has been reported from oceanic rocks generated in small marginal basins, such as those from the atypical BAB of Okinawa [63]. The wide range of compositions of the non-cumulative gabbros from the Dongco area most likely suggests that their genesis happened in an intra-ocean arc-BAB environment [27]. We note that Jurassic radiolarian cherts are generally missing in the Dongco area. This is against a possible formation of the investigated gabbros in a mature oceanic basin along the middle-western part of the BNSZ. It rather implies that the non-cumulative gabbros from Dongco represent vestiges of an oceanic lithosphere that was formed in a small transient BAB over a short period of time [34].

In the $\mathrm{TiO}_{2} / \mathrm{Yb}-\mathrm{Nb} / \mathrm{Yb}$ discrimination diagram, the Dongco gabbros plot in the shallow melting array, showing comparable compositions to those of typical MORB-type tholeiites (Figure 10b). This implies derivation of the parental magmas of the investigated gabbros from melting of a spinel-bearing mantle source [64,65]. Furthermore, the chondrite-normalized REE patterns of the non-cumulative gabbros from Dongco are generally more depleted in HREE compared to those of typical N-MOR basalts (Figure 5c). This most likely indicates that the parental magmas of the investigated gabbros were derived from heterogeneous melting of a depleted mantle source region. This is consistent with the positive $\varepsilon_{\mathrm{Nd}}(\mathrm{t})$ values of the non-cumulative gabbros from the Dongco area (Figure $8 b$ ) [66,67]. Furthermore, in the $\varepsilon_{\mathrm{Hf}}(\mathrm{t})$ versus U-Pb age diagram analyses of zircons separated from the Dongco, gabbros fall between the DM- and CHUR-control lines, indicating crystallization from magmas derived from melting of a heterogeneously depleted juvenile mantle source [68].

Previous studies reported radiometric ages for the Dongco ophiolite ranging from $222.5 \pm 4.8 \mathrm{Ma}$ to $104.0 \pm 4.07 \mathrm{Ma}$ based on the Sm-Nd, K-Ar, Ar-Ar, and U-Pb dating methods $[25,27,33,36,39,40]$. In this study, we dated zircons separated from a relative fresh anorthosite sample (XDC08; Figure 6a). The resultant weighted mean ${ }^{206} \mathrm{~Pb} /{ }^{238} \mathrm{U}$ age of $169.0 \pm 3.7 \mathrm{Ma}$ age is generally consistent with 
the reported $\mathrm{U}-\mathrm{Pb}$ ages of zircons separated from a cumulate hornblende-gabbro and a cumulate gabbro from Dongco $(166.0 \pm 3.7 \mathrm{Ma})$ [36] and $(167.0 \pm 2 \mathrm{Ma})$ [27], respectively. Furthermore, the Dongco ophiolite experienced amphibolite-facies metamorphism during the Early to Middle Jurassic (167.0 \pm 7.2 Ma-177.6 $\pm 3.3 \mathrm{Ma})$ [34]. This metamorphic episode was probably a result of the northward subduction of the BNTO beneath the southern margin of the Qiangtang terrane [21,22] and was almost contemporaneous with the igneous accretion of the Dongco ophiolite.

Our preferred hypothesis for the genesis of the non-cumulative gabbros of the Dongco ophiolite is that their parental magmas were derived from variable degrees of melting of a heterogeneously depleted, juvenile spinel-bearing mantle reservoir beneath a transient BAB setting in the Middle Jurassic.

\subsection{Petrogenesis of the Lanong Gabbros}

Previous studies have proposed diverse origins for the Lanong ophiolite, including a back-arc setting [41] and a forearc setting [28].

In the $\mathrm{Th}-\mathrm{Nb} / 16-\mathrm{Hf} / 3$ and $\mathrm{MnO} \times 10-\mathrm{P}_{2} \mathrm{O}_{5} \times 10-\mathrm{TiO}_{2}$ ternary diagrams, the compositions of the non-cumulative gabbros from the Lanong area straddle the boundaries of the fields of rocks with IAT and boninitic affinities (Figure $9 \mathrm{a}, \mathrm{b}$ ). In the $\mathrm{Th} / \mathrm{Yb}-\mathrm{Nb} / \mathrm{Yb}$ proxy diagram, the plots of the investigated gabbros show a general enrichment in Th (Figure 10a) consistent with a minor input of subducted crustal materials in the source region of their parental magmas. This is also supported by the PM-normalized trace element patterns of the investigated gabbros showing negative $\mathrm{Nb}( \pm \mathrm{Ti})$ anomalies (Figure 5b,d) $[13,69]$. Therefore, it can be inferred that the genesis of the non-cumulative gabbros from Lanong happened in an arc-related geotectonic environment.

In the $\mathrm{TiO}_{2} / \mathrm{Yb}-\mathrm{Nb} / \mathrm{Yb}$ discrimination diagram, the non-cumulative gabbros from the Lanong area plot in the shallow melting array (Figure 10b), indicating derivation of their parental magmas from melting of a spinel-bearing mantle reservoir [64,65]. The chondrite-normalized REE patterns of the non-cumulative gabbros of Lanong do not show great variations in the HREE contents. In addition, the investigated gabbros contain magmatic zircons with positive $\varepsilon_{\mathrm{Hf}}(\mathrm{t})$ values (Figure $8 \mathrm{a}$ ). Therefore, the parental magmas of the non-cumulative gabbros from Lanong were probably derived from near homogeneous melting of a juvenile mantle source.

Dating of magmatic zircons separated from an anorthosite (16XLN03-1; Figure 6b) and a gabbro sample (16XLN07-1; Figure 6c) from the Lanong ophiolite yielded weighted average ${ }^{206} \mathrm{~Pb} /{ }^{238} \mathrm{U}$ ages of $166.8 \pm 0.9 \mathrm{Ma}$ (Figure 7d) and 167.3 $\pm 1.1 \mathrm{Ma}$ (Figure 7e), respectively. These Middle Jurassic ages could be interpreted as the time of the igneous accretion of the Lanong oceanic crust.

The compositional data of the non-cumulative gabbros from the Lanong area indicate that they were likely formed in a forearc setting. This forearc basin was most likely produced in response to the northward subduction of the BNTO during the Middle Jurassic. This is consistent with the Middle Jurassic ages previously reported for the high-Mg andesites from the near Darutso area $(163.3 \pm 1.7 \mathrm{Ma})[70](161.5 \pm 0.9 \mathrm{Ma}$ and $164.2 \pm 1.4 \mathrm{Ma})$ [71]. The Darutso andesites were derived from high- $T$ and low- $P$ melting of a mantle source influenced by the input of subducted components [71]. A forearc setting formed due to subduction initiation has been inferred as the ideal geotectonic environment for the Darutso andesites [71]. This scenario could also be invoked to explain the genesis of the non-cumulative gabbros from Lanong.

\subsection{Implications for the Geotectonic Evolution of the BNTO}

Our data support the idea that the non-cumulative gabbros from the Dongco and Lanong areas were formed in transient $\mathrm{BAB}$ and forearc settings, respectively, during the Middle Jurassic. These findings urged us to reconsider the existing geodynamic models for the Mesozoic petrotectonic evolution of the BNTO.

The documentation of melt-rock interaction processes between refractory harzburgites and MOR-type basaltic magmas in the ophiolite outcrops of the middle-western BNSZ has been viewed as a result of a tectono-magmatic event linked to the genesis of Meso-Tethys [72]. This interpretation is 
corroborated by the discovery of MORB-type gabbros with an average age of $231.5 \pm 2.6 \mathrm{Ma}$ in the central parts of the BNSZ [73]. For that reason, it is concluded that the opening of the BNTO began during the Permian-Triassic. The occurrence of Jurassic intraplate magmatic rocks in the Dongco area [25] implies that the middle-western BNTO was still spreading during the Jurassic (Figure 11a). However, a strong line of petrologic evidence indicates that the middle-western BNTO had started subducting under the southern margin of the Qiangtang terrane since the Late Triassic-Early Jurassic. For instance, Jurassic arc-type volcanic rocks are widespread along the southern margin of the Qiangtang terrane (Figure 11b; Table S6). These rocks contain zircons with lower $\varepsilon_{\mathrm{Hf}}(\mathrm{t})$ values than those of zircons contained in the BNSZ ophiolitic rocks, most likely indicating the formation of an active continental margin $[28,71,74]$.
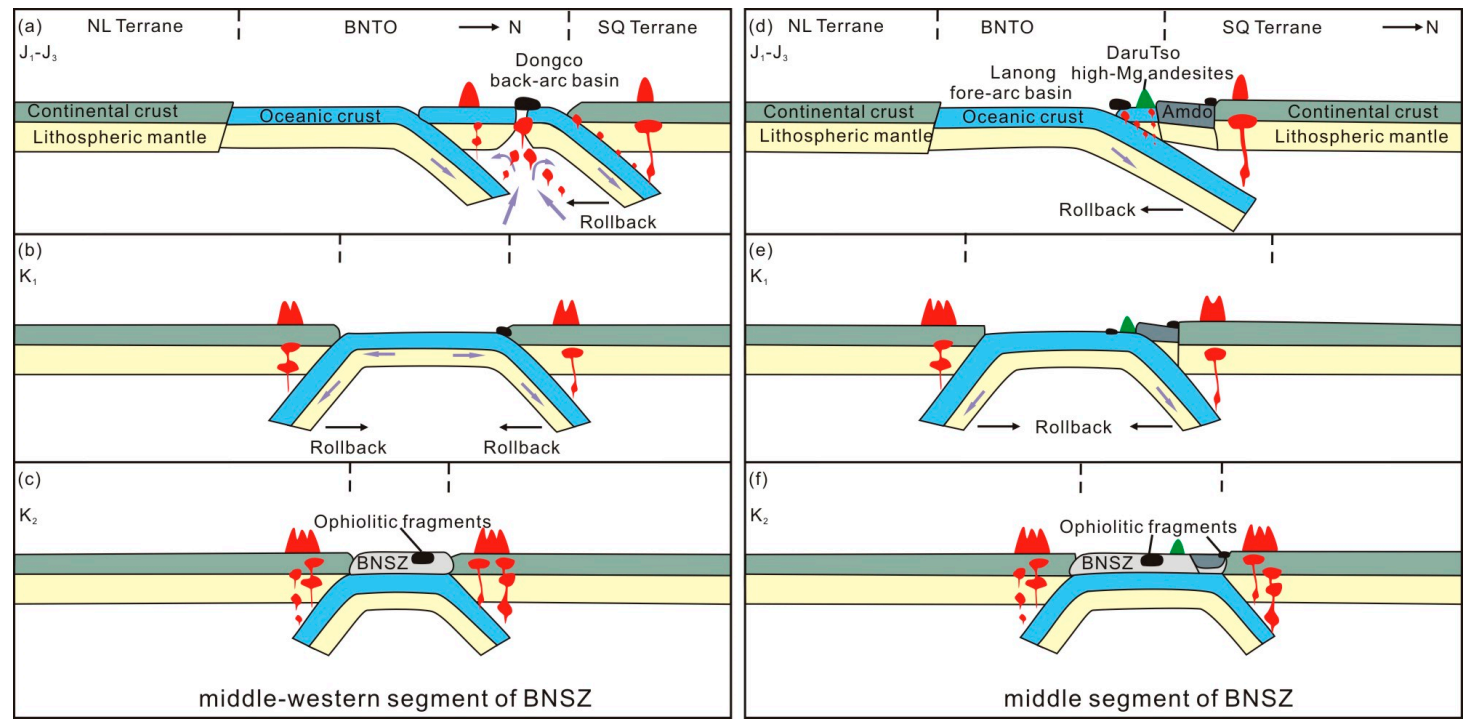

Figure 11. Schematic cartoon model illustrating various stages in the geotectonic evolution of the middle-western $(\mathbf{a}-\mathbf{c})$ and middle $(\mathbf{d}-\mathbf{f})$ segments of the BNTO during the Mesozoic.

Geochronological dating of SSZ-type ophiolitic rocks from the middle segment of the BNSZ yielded ages of $251.0 \pm 65.0 \mathrm{Ma}$ [75]. These ages were interpreted as marking a period of lithospheric slab subduction in the middle part of the BNTO. Therefore, it is believed that the middle segment of the BNSZ corresponds to an Early Jurassic intra-oceanic subduction zone. This was also confirmed by petrologic-geochronological studies carried out in the Amdo basement $(177.0 \pm 2.0 \mathrm{Ma}$ to $188.0 \pm 2.0 \mathrm{Ma})[27,76]$, Dongqiao $(181.4 \pm 1.3 \mathrm{Ma}$ to $188.4 \pm 1.2 \mathrm{Ma})[27,77,78]$, Jiang Tso $(188.1 \pm 4.1 \mathrm{Ma}$ to $189.8 \pm 3.3 \mathrm{Ma}$ ) [79,80], and Nagqu areas $(183.7 \pm 1.0 \mathrm{Ma})$ [81]. Since the Middle Jurassic, forearc oceanic lithosphere had started forming in the Kangqiong (165.0 \pm 2.5$)$ [82], Dongqiao (181.4 $\pm 1.3 \mathrm{Ma}$, $188.4 \pm 1.2 \mathrm{Ma})$ [78], and Lanong $(166.8 \pm 0.9 \mathrm{Ma}, 167.3 \pm 1.1 \mathrm{Ma})$ [this study] areas. This is also supported by the occurrence of arc-related high-Mg andesites of Middle Jurassic age in the Darutso area, which are interpreted as rocks that were formed in a convergent margin setting rather than in a continental extensional environment (Figure 11d) [70,71]. Although the Amdo terrane was regarded as another separate ancient microcontinent [29,71], it had been evolved to be a part of the south Qiangtang terrane since the Jurassic [20]. Therefore, our preferred hypothesis for the genesis of the ophiolitic outcrops of the middle segment of the BNSZ is that they were formed in a forearc basin along the northward subduction of the BNTO in the Middle Jurassic (Figure 11d).

Arc-related mafic rocks are found tectonically emplaced onto the margins of the north Lhasa [19,29,30,83-88] and south Qiangtang terranes [30,74,89-93]. Zircons separated from these mafic rocks have $\varepsilon_{\mathrm{Hf}}(\mathrm{t})$ values in the range of -20 to $+20[30,94]$, implying that the geotectonic status of the BNTO in the Cretaceous could be described by a divergent double subduction system (Figure 11b,c,e,f; Table S6) [93-97]. The divergent double subduction system aided asthenosphere upwelling that induced anatexis of the lower mafic crust and melting of the mantle in the wedge along 
the north Lhasa and south Qiangtang terranes. We suggest that the closure of the BNTO occurred no later than the Late Cretaceous as indicated by the ages of post-extensional volcanic rocks and flysch deposits along the BNSZ [23-26,30,98]. This interpretation is consistent with our observation that the Dongco ophiolites are unconformably overlain by the limestones of the Cretaceous Langshan Formation ( $\mathrm{K}_{1} l$; Figure $3 \mathrm{a}$ ) and the fact that the Lanong ophiolites are overlain by the Late Cretaceous Jingzhushan Formation $\left(\mathrm{K}_{2} j\right.$; Figure $\left.4 \mathrm{a}\right)$.

\section{Conclusions}

The most important findings of the present study are the following:

1. Uranium-Pb dating of magmatic zircons separated from the Dongco anorthosites yielded an average crystallization age of $169.0 \pm 3.7 \mathrm{Ma}$, whereas $\mathrm{U}-\mathrm{Pb}$ dating of igneous zircons recovered from the Lanong anorthosites and gabbros yielded mean crystallization ages of $166.8 \pm 0.9 \mathrm{Ma}$ and $167.3 \pm 1.1 \mathrm{Ma}$, respectively.

2. Geochemical and $\mathrm{Sr}-\mathrm{Nd}$ isotopic compositions show that the non-cumulative gabbros from Dongco and Lanong have SSZ-like affinities and were formed by melting of heterogeneously depleted mantle sources influenced by limited inputs of subducted crustal components.

3. The positive $\varepsilon_{\mathrm{Hf}}(\mathrm{t})$ values of the zircons recovered from the investigated mafic rocks imply derivation from juvenile mantle sources.

4. The non-cumulative gabbros from Dongco were formed in a transient BAB environment, whereas the non-cumulative gabbros from Lanong were formed in a forearc setting. Both geotectonic settings were related to the northward subduction of the BNTO in the Middle Jurassic.

Supplementary Materials: The following are available online at http://www.mdpi.com/2075-163X/9/8/466/s1, Supplementary Materials File 1: A Figure S1 show a relations between the selected trace elements (ppm) and Zr (ppm) of the Dongco and Lanong ophiolites and all tables (Tables S1-S6) including ages of ophiolitic fragments from Bangong-Nujiang Suture Zone (BNSZ), whole-rock geochemistry (including standards rocks), Sr-Nd isotopic and in situ Hf isotopes of Dongco and Lanong ophiolitic gabbros and anorthosites, and ages of arc-related rocks from the Northern Lhase terrane and Southern Qiangtang terrane. Figure S1: Selected trace elements (ppm) versus $\mathrm{Zr}$ (ppm) diagrams of the Dongco and Lanong ophiolites for evaluating element mobility during low-medium temperature hydrothermal alteration; Table S1: Ages of ophiolitic fragments from Bangong-Nujiang Suture Zone (BNSZ), central Tibetan; Table S2: Whole-rock major (wt \%), and trace elements (ppm; including REEs) data of Dongco and Lanong ophiolitic anorthosites and gabbros in the middle segments of Bangon-Nujiang Suture Zone (BNSZ), central Tibetan Plateau; Table S3: Zircon U-Pb ages data of Dongco ophiolitic anorthosite (XDC08) and Lanong ophiolitic anorthosite (16XLN03-1) and gabbro (16XLN07-1); Table S4: Zircon Hf isotopic data of the anorthosite samples from the Dongco (XDC08) and Lanong (16XLN03-1) ophiolites; Table S5: Whole-rock $\mathrm{Sr}-\mathrm{Nd}$ isotopic data of the anorthosite and gabbro samples from the Dongco (XDC08) and Lanong (16XLN03-1) ophiolites; Table S6: Ages of magmatic rocks from the Northern Lhase terrane and Southern Qiangtang terrane, Tibetan Plateau. Supplementary Materials File 2: Analytical methods of whole-rock geochemistry, zircon U-Pb dating, $\mathrm{Sr}-\mathrm{Nd}$ isotopic and in situ Hf isotopes.

Author Contributions: Conceptualization, P.Y., R.Z., A.K., and B.X.; Data curation, P.Y., Q.H., R.Z., A.K., Z.R., Z.C., and C.C.; Formal analysis, Q.H., A.K., and X.L.; Funding acquisition, Q.H., and B.X.; Investigation, P.Y., Q.H., B.X., X.L., and C.C.; Methodology, P.Y., R.Z., A.K., B.X., Z.R., Z.C., and X.L.; Resources, B.X., and Z.R.; Software, P.Y., R.Z., X.L., and C.C.; Supervision, Q.H., R.Z., B.X., and Z.R.; Validation, A.K., Z.R., and Z.C.; Writing-original draft, P.Y., Q.H., R.Z., A.K.; Writing-review and editing, P.Y., Q.H., R.Z., A.K., and Z.R.

Funding: This research was funded by the National Natural Science Foundation of China (No. 41602231), the Nature Science Foundation of Guangdong Province (No. 2018B030311030), the China Geological Survey Project (Nos. 1212011121087 and 1212011221088) and the Fundamental Research Funds for the Central Universities of China (Grant 171gpy60). Peng Yang was supported by the International Program for Ph.D. Candidates of Sun Yat-sen University, Guangzhou, China.

Acknowledgments: We would like to express our gratitude to Guo-qing Zhou for sharing some ideas on the petrogenesis of the investigated ophiolites. We appreciate three anonymous reviewers and editors, especially academic editor for their constructive reviews that have significantly improved the quality of this paper. We thank Kaijun Zhang, Paul Kapp, Federico Rossetti, and Solomon Buckman, Danling Chen and Jiahui Qian for their helpful suggestions. We are also thankful to Zhong-yu Xia, Xi-chong Hu, Xiao-long Shi and Zhi-long Wang for their assistance during the field work. We are indebted to Xiao-ping Xia, Qing Yang and Liang Li for their help during the analytical work. Assistant editor edited the publication format of this article.

Conflicts of Interest: The authors declare no conflict of interest. 


\section{References}

1. Dilek, Y.; Furnes, H. Ophiolite genesis and global tectonics: Geochemical and tectonic fingerprinting of ancient oceanic lithosphere. Geol. Soc. Am. Bull. 2011, 123, 387-411. [CrossRef]

2. Dilek, Y.; Furnes, H. Ophiolites and Their Origins. Elements 2014, 10, 93-100. [CrossRef]

3. Moores, E.M. Origin and emplacement of ophiolites. Rev. Geophy. 1982, 20, 735-760. [CrossRef]

4. Moores, E.M.; Kellogg, L.H.; Dilek, Y. Tethyan ophiolites, mantle convection, and tectonic "historical contingency": A resolution of the "ophiolite conundrum". In Ophiolites and Oceanic Crust: New Insights from Field Studies and the Ocean Drilling Program: Boulder; Dilek, Y., Moores, E.M., Elthon, D., Nicolas, A., Eds.; Colorado Geological Society of America: Boulder, CO, USA, 2000; Volume 349, pp. 3-12.

5. Morris, A.; Maffione, M. Is the Troodos ophiolite (Cyprus) a complete, transform fault-bounded Neotethyan ridge segment? Geology 2016, 44, 199-202. [CrossRef]

6. Dewey, J.F.; Bird, J.M. Origin and Emplacement of the Ophiolite Suite: Appalachian Ophiolites in Newfoundland. J. Geophys. Res. 1971, 76, 3179-3206. [CrossRef]

7. Kidd, R.G.W.; Cann, J.R. Chilling statistics indicate an ocean-floor spreading origin for the Troodos complex, Cyprus. Earth Planet. Sci. Lett. 1974, 24, 151-155. [CrossRef]

8. Rassios, A.E.; Dilek, Y. Rotational deformation in the Jurassic Mesohellenic ophiolites, Greece, and its tectonic significance. Lithos 2009, 108, 207-223. [CrossRef]

9. Boudier, F.; Nicolas, A. Axial melt lenses at oceanic ridges-A case study in the Oman ophiolite. Earth Planet. Sci. Lett. 2011, 304, 313-325. [CrossRef]

10. Cowan, R.J.; Searle, M.P.; Waters, D.J. Structure of the metamorphic sole to the Oman Ophiolite, Sumeini Window and Wadi Tayyin: Implications for ophiolite obduction processes. Geol. Soc. Lond. Spec. Publ. 2014, 392, 155-175. [CrossRef]

11. Dilek, Y. Ophiolite concept and its evolution. Geol. Soc. Am. Spec. Pap. 2003, 373, 1-16.

12. Pearce, J.A.; Lippard, S.J.; Roberts, S. Characteristics and tectonic significance of supra-subduction zone ophiolites. Geol. Soc. Lond. Spec. Publ. 1984, 16, 77-94. [CrossRef]

13. Zheng, H.; Huang, Q.; Kapsiotis, A.; Lenaz, D.; Velicogna, M.; Xu, C.; Cheng, C.; Xia, B.; Liu, W.; Xiao, Y.; et al. Coexistence of MORB- and OIB-like dolerite intrusions in the Purang ultramafic massif, SW Tibet: A paradigm of plume-influenced MOR-typemagmatism prior to subduction initiation in the Neo-Tethyan lithospheric mantle. Geol. Soc. Am. Bull. 2019, 131, 1276-1294. [CrossRef]

14. Dilek, Y.; Flower, M.F.J. Arc-trench rollback and fore-arc accretion: 2. A model template for ophiolites in Albania, Cyprus, and Oman. Geol. Soc. Lond. Spec. Publ. 2003, 218, 43-68. [CrossRef]

15. Pickett, E.A.; Robertson, A.H.F. Formation of the Late Palaeozoic-Early Mesozoic Karakaya Complex and related ophiolites in NW Turkey by Palaeotethyan subduction-accretion. J. Geol. Soc. 1996, 145, 393-400. [CrossRef]

16. Gnos, E.; Immenhauser, A.; Peters, T. Late Cretaceous/early Tertiary convergence between the Indian and Arabian plates recorded in ophiolites and related sediments. Tectonophysics 1997, 271, 1-19. [CrossRef]

17. Yin, A.; Harrison, T.M. Geologic Evolution of the Himalayan-Tibetan Orogen. Annu. Rev. Earth Planet. Sci. 2000, 28, 211-280. [CrossRef]

18. Pan, G.T.; Wang, L.Q.; Li, R.S.; Yuan, S.H.; Ji, W.H.; Yin, F.G.; Zhang, W.P.; Wang, B.D. Tectonic evolution of the Qinghai-Tibet Plateau. J. Asian Earth Sci. 2012, 53, 3-14. [CrossRef]

19. Zhu, D.C.; Zhao, Z.D.; Niu, Y.L.; Dilek, Y.; Hou, Z.Q.; Mo, X.X. The origin and pre-Cenozoic evolution of the Tibetan Plateau. Gondwana Res. 2013, 23, 1429-1454. [CrossRef]

20. Guynn, J.H.; Kapp, P.; Pullen, A.; Heizler, M.; Gehrels, G.; Ding, L. Tibetan basement rocks near Amdo reveal "missing" Mesozoic tectonism along the Bangong suture, central Tibet. Geology 2006, 34, 505-508. [CrossRef]

21. Girardeau, J.; Marcoux, J.; Allègre, C.J.; Bassoullet, J.P.; Youking, T.; Xiao, X.C.; Zao, Y.G.; Wang, X.B. Tectonic environment and geodynamic significance of the Neo-Cimmerian Donqiao ophiolite, Bangong-Nujiang suture zone, Tibet. Nature 1984, 307, 27-31. [CrossRef]

22. Pearce, J.A.; Deng, W.M. The Ophiolites of the Tibetan Geotraverses, Lhasa to Golmud (1985) and Lhasa to Kathmandu (1986). Philos. Trans. R. Soc. Lond. Ser. A Math. Phys. Sci. 1988, 327, 215-238. [CrossRef]

23. Zhang, K.J. Secular geochemical variations of the Lower Cretaceous siliciclastic rocks from central Tibet (China) indicate a tectonic transition from continental collision to back-arc rifting. Earth Planet. Sci. Lett. 2004, 229, 73-89. [CrossRef] 
24. Zhang, K.J.; Xia, B.D.; Wang, G.M.; Li, Y.T.; Ye, H.F. Early Cretaceous stratigraphy, depositional environment, sandstone provenance, and tectonic setting of central Tibet, western China. Geol. Soc. Am. Bull. 2004, 116, 1202-1222. [CrossRef]

25. Zhang, K.J.; Xia, B.; Zhang, Y.X.; Liu, W.L.; Zeng, L.; Li, J.F.; Xu, L.F. Central Tibetan Meso-Tethyan oceanic plateau. Lithos 2014, 210-211, 278-288. [CrossRef]

26. Zhang, K.J.; Zhang, Y.X.; Tang, X.C.; Xia, B. Late Mesozoic tectonic evolution and growth of the Tibetan plateau prior to the Indo-Asian collision. Earth Sci. Rev. 2012, 114, 236-249. [CrossRef]

27. Wang, B.D.; Wang, L.Q.; Chung, S.L.; Chen, J.L.; Yin, F.G.; Liu, H.; Li, X.B.; Chen, L.K. Evolution of the Bangong-Nujiang Tethyan ocean: Insights from the geochronology and geochemistry of mafic rocks within ophiolites. Lithos 2016, 245, 18-33. [CrossRef]

28. Zhong, Y.; Liu, W.L.; Xia, B.; Liu, J.N.; Guan, Y.; Yin, Z.X.; Huang, Q.T. Geochemistry and geochronology of the Mesozoic Lanong ophiolitic mélange, northern Tibet: Implications for petrogenesis and tectonic evolution. Lithos 2017, 292-293, 111-131. [CrossRef]

29. Zhu, D.C.; Zhao, Z.D.; Niu, Y.L.; Mo, X.X.; Chung, S.L.; Hou, Z.Q.; Wang, L.Q.; Wu, F.Y. The Lhasa Terrane: Record of a microcontinent and its histories of drift and growth. Earth Planet. Sci. Lett. 2011, 301, 241-255. [CrossRef]

30. Zhu, D.C.; Li, S.M.; Cawood, P.A.; Wang, Q.; Zhao, Z.D.; Liu, S.A.; Wang, L.Q. Assembly of the Lhasa and Qiangtang terranes in central Tibet by divergent double subduction. Lithos 2016, 245, 7-17. [CrossRef]

31. Zhou, M.F.; Malpas, J.; Robinson, P.T.; Reynolds, P.H. The dynamothermal aureole of the Donqiao ophiolite (northern Tibet). Can. J. Earth. Sci. 1997, 34, 59-65. [CrossRef]

32. Fan, J.J.; Li, C.; Xie, C.M.; Wang, M.; Chen, J.W. Petrology and U-Pb zircon geochronology of bimodal volcanic rocks from the Maierze Group, northern Tibet: Constraints on the timing of closure of the Banggong-Nujiang Ocean. Lithos 2015, 227, 148-160. [CrossRef]

33. Bao, P.S.; Xiao, X.C.; Su, L.; Wang, J. Petrological, geochemical and chronological constraints for the tectonic setting of the Dongco ophiolite in Tibet. Sci. China Ser. D Earth Sci. 2007, 50, 660-671. [CrossRef]

34. Wang, W.L.; Aitchison, J.C.; Lo, C.H.; Zeng, Q.G. Geochemistry and geochronology of the amphibolite blocks in ophiolitic mélanges along Bangong-Nujiang suture, central Tibet. J. Asian Earth Sci. 2008, 33, 122-138. [CrossRef]

35. Li, J.F.; Xia, B.; Wang, R.; Liu, W.L. Mineralogical characteristics of the Dong Tso ophiolite and its tectonic implications. Geotecton. Metallog. 2013, 37, 308-319.

36. Li, J.F.; Xia, B.; Xia, L.Z.; Xu, L.F.; Liu, W.L.; Cai, Z.R.; Yang, Z.Q. Geochronology of the Dong Tso Ophiolite and the Tectonic Environment. Acta Geol. Sin. (Engl. Ed.) 2013, 87, 1604-1616. [CrossRef]

37. Xia, B. Ophiolite and Tectonostratigraphic Terrane Map of Himalaya and Adjacent Areas. Scale 1:2,500,000; Gansu Science and Technology Publishing House: Lanzhou, China, 1993. (In Chinese)

38. Wang, X.B.; Bao, P.S.; Deng, W.M. Xizang (Tibet) Ophiolites; Ecological Publishing House: Beijing, China, 1987. (In Chinese)

39. Qiu, R.Z.; Zhou, S.; Deng, J.F.; Li, J.F.; Xiao, Q.H.; Cai, Z.Y. Dating of gabbro in the Shemalagou ophiolite in the western segment of the Bangong Co-Nujiang ophiolite belt, Tibet-with a discussion of the age of the Bangong Co-Nujiang ophiolite belt. Geol. China 2004, 31, 262-268.

40. Wu, Y.; Chen, S.Y.; Qin, M.K.; Guo, D.F.; Guo, G.L.; Zhang, C.; Yang, J.S. Zircon U-Pb Ages of the Dongcuo Ophiolite in the Western Bangong-Nujiang Suture Zone and Their Geological Significance. Earth Sci. J. China Univ. Geosci. 2018, 43, 1070-1084.

41. Xu, L.F.; Xia, B.; Li, J.F.; Zhong, L.F. Geochemical Characteristics and Genesis of Pillow Basalts from the Lanong Ophiolite in Tibet, China. Geotecton. Metallog. 2010, 34, 105-113.

42. Sun, S.S.; McDonough, W.F. Chemical and isotopic systematics of oceanic basalts: Implications for mantle composition and processes. Geol. Soc. Lond. Spec. Publ. 1989, 42, 313-345. [CrossRef]

43. Hoskin, P.W.O.; Black, L.P. Metamorphic zircon formation by solid-state recrystallization of protolith igneous zircon. J. Metamorph. Geol. 2000, 18, 423-439. [CrossRef]

44. Cheng, C.; Zheng, H.; Kapsiotis, A.; Liu, W.; Lenaz, D.; Velicogna, M.; Zhong, L.; Huang, Q.; Yuan, Y.; Xia, B. Geochemistry and geochronology of dolerite dykes from the Daba and Dongbo peridotite massifs, SW Tibet: Insights into the style of mantle melting at the onset of Neo-Tethyan subduction. Lithos 2018, 322, 281-295. [CrossRef] 
45. Chu, Z.Y.; Wu, F.Y.; Walker, R.J.; Rudnick, R.L.; Pitcher, L.; Puchtel, I.S.; Yang, Y.H.; Wilde, S.A. Temporal evolution of the lithospheric mantle beneath the eastern North China Craton. J. Petrol. 2009, 50, 1857-1898. [CrossRef]

46. Xiao, Y.; Zhang, H.F.; Fan, W.M.; Ying, J.F.; Zhang, J.; Zhao, X.M.; Su, B.X. Evolution of lithospheric mantle beneath the Tan-Lu fault zone, eastern North China Craton: Evidence from petrology and geochemistry of peridotite xenoliths. Lithos 2010, 117, 229-246. [CrossRef]

47. Xiao, L.; Xu, Y.G.; Mei, H.J.; Zheng, Y.F.; He, B.; Pirajno, F. Distinct mantle sources of low-Ti and high-Ti basalts from the western Emeishan large igneous province, SW China: Implications for plume-lithosphere interaction. Earth Planet. Sci. Lett. 2004, 228, 525-546. [CrossRef]

48. Xu, Y.G.; Chung, S.L.; Jahn, B.M.; Wu, G.Y. Petrologic and geochemical constraints on the petrogenesis of Permian-Triassic Emeishan flood basalts in southwestern China. Lithos 2001, 58, 145-168. [CrossRef]

49. Pearce, J.A.; Cann, J.R. Tectonic Setting of Basic Volcanic Rocks determined using Trace Element Analyses. Earth Planet. Sci. Lett. 1973, 19, 290-300. [CrossRef]

50. Wood, D.A. The application of a Th-Hf-Ta diagram to problems of tectonomagmatic classification and to establishing the nature of crustal contamination of basaltic lavas of the British Tertiary Volcanic Province. Earth Planet. Sci. Lett. 1980, 50, 11-33. [CrossRef]

51. Zou, H.B.; Zindler, A.; Xu, X.S.; Qi, Q. Major, trace element, and Nd, Sr and Pb isotope studies of Cenozoic basalts in SE China: Mantle sources, regional variations, and tectonic significance. Chem. Geol. 2000, 171, 33-47. [CrossRef]

52. Taylor, S.R.; McLennan, S.M. The Continental Crust: Its Composition and Evolution; Blackwell Science Publishing: Oxford, UK, 1985; pp. 1-312.

53. Irvine, T.N. Layering and related structures in the Duke Island and Skaergaard intrusions: Similarities, differences and origins. In Origin of Igneous Layering; Parson, I., Ed.; NATO ASI Series, Serie. C; Springer: New York, NY, USA, 1987; Volume 196, pp. 185-245.

54. Morales, L.F.G.; Boudier, F.; Nicolas, A. Microstructures and crystallographic preferred orientation of anorthosites from Oman ophiolite and the dynamics of melt lenses. Tectonics 2011, 30, TC2011. [CrossRef]

55. Boudier, F.; Nicolas, A.; Ildefonse, B. Magma chambers in the Oman ophiolite: Fed from the top or from the bottom? Earth Planet. Sci. Lett. 1996, 144, 239-250. [CrossRef]

56. Kapsiotis, A.; Ewing-Rassios, A.; Grieco, G.; Antonelou, A. Genesis of Cr bearing hydrogrossular-rich veins in a chromitite boulder from Ayios Stefanos, West Othris, Greece: A paradigm of micro-rodingites formation at the late stages of oceanic slab emplacement. Ore Geol. Rev. 2017, 90, 287-306. [CrossRef]

57. Zhang, K.J.; Li, Q.H.; Yan, L.L.; Zeng, L.; Lu, L.; Zhang, Y.X.; Hui, J.; Jin, X.; Tang, X.C. Geochemistry of limestones deposited in various plate tectonic settings. Earth Sci. Rev. 2017, 167, 27-46. [CrossRef]

58. Mullen, E.D. $\mathrm{MnO}-\mathrm{TiO}_{2}-\mathrm{P}_{2} \mathrm{O}_{5}$ : A minor element discriminant for basaltic rocks of oceanic environments and its implications for petrogenesis. Earth Planet. Sci. Lett. 1983, 62, 53-62. [CrossRef]

59. Pearce, J.A. Geochemical fingerprinting of oceanic basalts with applications to ophiolite classification and the search for Archean oceanic crust. Lithos 2008, 100, 14-48. [CrossRef]

60. Dilek, Y.; Furnes, H.; Shallo, M. Geochemistry of the Jurassic Mirdita Ophiolite (Albania) and the MORB to SSZ evolution of a marginal basin oceanic crust. Lithos 2008, 100, 174-209. [CrossRef]

61. Dilek, Y.; Thy, P. Island arc tholeiite to boninitic melt evolution of the Cretaceous Kizildag (Turkey) ophiolite: Model for multi-stage early arc-forearc magmatism in Tethyansubduction factories. Lithos 2009, 113, 68-87. [CrossRef]

62. Godard, M.; Dautria, J.M.; Perrin, M. Geochemical variability of the Oman ophiolite lavas: Relationship with spatial distribution and paleomagnetic directions. Geochem. Geophys. Geosyst. 2003, 4, 8609. [CrossRef]

63. Shinjo, R.; Chung, S.L.; Kato, Y.; Kimura, M. Geochemical and Sr-Nd isotopic characteristics of volcanic rocks from the Okinawa Trough and Ryukyu Arc: Implications for the evolution of a young, intracontinental back arc basin. J. Geophys. Res. Solid Earth 1999, 104, 10591-10608. [CrossRef]

64. Aldanmaz, E.; Pearce, J.A.; Thirlwall, M.F.; Mitchell, J.G. Petrogenetic evolution of the late Cenozoic, post-collision volcanism in western Anatolia, Turkey. J. Volcanol. Geoth. Res. 2000, 102, 67-95. [CrossRef]

65. Saccani, E.; Photiades, A.; Beccaluva, L. Petrogenesis and tectonic significance of Jurassic IAT magma types in the Hellenide ophiolites as deduced from the Rhodiani ophiolites (Pelagonian zone, Greece). Lithos 2008, 104, 71-84. [CrossRef]

66. Zindler, A.; Hart, S. Chemical Geodynamics. Annu. Rev. Earth Planet. Sci. 1986, 14, 493-571. [CrossRef] 
67. Wilson, M.B. Igneous Petrogenesis, A Global Tectonic Approach; Springer Science \& Business Media: Berlin, Germany, 1989; pp. 1-466.

68. Belousova, E.A.; Jiménez, J.M.G.; Graham, I.; Griffin, W.L.; O’Reilly, S.Y.; Pearson, N.; Martin, L.; Craven, S.; Talavera, C. The enigma of crustal zircons in uppermantle rocks: Clues from the Tumut ophiolite, southeast Australia. Geology 2015, 43, 119-122. [CrossRef]

69. Zhou, M.F.; Robinson, P.T.; Lesher, C.M.; Keays, R.R.; Zhang, C.J.; Malpas, J. Geochemistry, petrogenesis and metallogenesis of the Panzhihua gabbroic layered intrusion and associated Fe-Ti-V oxide deposits, Sichuan province, SW China. J. Petrol. 2005, 46, 2253-2280. [CrossRef]

70. Li, X.B.; Wang, B.D.; Liu, H.; Wang, L.Q.; Chen, L. The Late Jurassic high-Mg andesites in the Daru Tso area, Tibet: Evidence for the subduction of the Bangong Co-Nujiang River oceanic lithosphere. Geol. Bull. China 2015, 34, 251-261.

71. Zeng, Y.C.; Chen, J.L.; Xu, J.F.; Wang, B.D.; Huang, F. Sediment melting during subduction initiation: Geochronological and geochemical evidence from the Darutso high-Mg andesites within ophiolite melange, central Tibet. Geochem. Geophys. Geosyst. 2016, 17, 4859-4877. [CrossRef]

72. Huang, Q.S.; Shi, R.D.; Ding, B.H.; Liu, D.L.; Zhang, X.R.; Fan, S.Q.; Zhi, X.C. Re-Os isotopic evidence of MOR-type ophiolite from the Bangong Co for the opening of Bangong-Nujiang Tethys Ocean. Acta Petrol. Mineral. 2012, 31, 465-478, (In Chinese with English Abstract).

73. Qin, Y.D.; Li, D.W.; Liu, D.M.; Li, H.L. Opening Time of Middle Tethys Oceanic Basin: Constrained from Zircon U-Pb Dating of MOR-type Gabbro in Bangong Lake Ophiolite. Geotecton. Metallog. 2017, 41, 1148-1157.

74. Hao, L.L.; Wang, Q.; Wyman, D.A.; Ou, Q.; Dan, W.; Jiang, Z.Q.; Wu, F.Y.; Yang, J.H.; Long, X.P.; Li, J. Underplating of basaltic magmas and crustal growth in a continental arc: Evidence from Late Mesozoic intermediate-felsic intrusive rocks in southern Qiangtang, central Tibet. Lithos 2016, 245, 223-242. [CrossRef]

75. Shi, R.D.; Griffin, W.L.; O’Reilly, S.Y.; Huang, Q.S.; Zhang, X.R.; Liu, D.L.; Zhi, X.C.; Xia, Q.X.; Ding, L. Melt/mantle mixing produces podiform chromite deposits in ophiolites: Implications of Re-Os systematics in the Dongqiao Neo-tethyan ophiolite, northern Tibet. Gondwana Res. 2012, 21, 194-206. [CrossRef]

76. Sun, L.X.; Bai, Z.D.; Xu, D.B.; Li, H.K.; Song, B. Geological Characteristics and Zircon U-Pb SHRIMP Dating of the Plagiogranite in Amduo ophiolites, Tibet. Geol. Surv. Res. 2011, 34, 10-15.

77. Xia, B.; Xu, L.F.; Wei, Z.Q.; Zhang, Y.Q.; Wang, R.; Li, J.F.; Wang, Y.B. SHRIMP zircon dating of gabbro from the Donqiao ophiolite in Tibet and its geological implications. Acta Geol. Sin. 2008, 82, 528-531.

78. Liu, T.; Zhai, Q.G.; Wang, J.; Bao, P.S.; Qiangba, Z.X.; Tang, S.H.; Tang, Y. Tectonic significance of the Dongqiao ophiolite in the north-central Tibetan plateau: Evidence from zircon dating, petrological, geochemical and Sr-Nd-Hf isotopic characterization. J. Asian Earth Sci. 2016, 116, 139-154. [CrossRef]

79. Huang, Q.T.; Li, J.F.; Cai, Z.R.; Xia, L.Z.; Yuan, Y.J.; Liu, H.C.; Xia, B. Geochemistry, Geochronology, Sr-Nd Isotopic Compositions of Jiang Tso Ophiolite in the Middle Segment of the Bangong-Nujiang Suture Zone and Their Geological Significance. Acta Geol. Sin. (Engl. Ed.) 2015, 89, 389-401.

80. Huang, Q.T.; Li, J.F.; Xia, B.; Yin, Z.X.; Zheng, H.; Shi, X.L.; Hu, X.C. Petrology, geochemistry, chronology and geological significance of JiangTso ophiolite in middle segment of Bangonghu-Nujiang suture zone, Tibet. Earth Sci. J. China Univ. Geosci. 2015, 40, 34-48.

81. Huang, Q.S.; Shi, R.D.; Liu, D.L.; Zhang, X.R.; Fan, S.Q.; Ding, L. Os isotopic evidence for a carbonaceous chondritic mantle source for the Nagqu ophiolite from Tibet and its implications. Chin. Sci. Bull. 2012, 58, 92-98. [CrossRef]

82. Xu, W.; Li, C.; Xu, M.J.; Wu, Y.W.; Fan, J.J.; Wu, H. Petrology, geochemistry, and geochronology of boninitic dikes from the Kangqiong ophiolite: Implications for the Early Cretaceous evolution of Bangong-Nujiang Neo-Tethys Ocean in Tibet. Int. Geol. Rev. 2015, 57, 2028-2043. [CrossRef]

83. Xu, R.H.; Schärer, U.; Allègre, C.J. Magmatism and Metamorphism in the Lhasa Block (Tibet): A Geochronological Study. J. Geol. 1985, 93, 41-57. [CrossRef]

84. Ji, W.Q.; Wu, F.Y.; Chung, S.L.; Li, J.X.; Liu, C.Z. Zircon U-Pb geochronology and Hf isotopic constraints on petrogenesis of the Gangdese batholith, southern Tibet. Chem. Geol. 2009, 262, 229-245. [CrossRef]

85. Haider, V.L.; Dunkl, I.; Eynatten, H.V.; Ding, L.; Frei, D.; Zhang, L. Cretaceous to Cenozoic evolution of the northern Lhasa Terrane and the Early Paleogene development of peneplains at Nam Co, Tibetan Plateau. J. Asian Earth Sci. 2013, 70-71, 79-98. [CrossRef] 
86. Sui, Q.L.; Wang, Q.; Zhu, D.C.; Zhao, Z.D.; Chen, Y.; Santosh, M.; Hu, Z.C.; Yuan, H.L.; Mo, X.X. Compositional diversity of ca. 110 Ma magmatism in the northern Lhasa Terrane, Tibet: Implications for the magmatic origin and crustal growth in a continent-continent collision zone. Lithos 2013, 168-169, 144-159. [CrossRef]

87. Volkmer, J.E.; Kapp, P.; Horton, B.K.; Gehrels, G.E.; Minervini, J.M.; Ding, L. Northern Lhasa thrust belt of central Tibet: Evidence of Cretaceous-early Cenozoic shortening within a passive roof thrust system? Geol. Soc. Am. Spec. Pap. 2014, 507, 59-70.

88. Huang, Q.T.; Cai, Z.R.; Xia, B.; Li, J.F.; Xia, L.Z.; Liu, H.C. Geochronology, geochemistry, and Sr-Nd-Pb isotopes of Cretaceous granitoids from western Tibet: Petrogenesis and tectonic implications for the evolution of the Bangong Meso-Tethys. Int. Geol. Rev. 2016, 58, 95-111. [CrossRef]

89. Kapp, P.; Yin, A.; Harrison, T.M.; Ding, L. Cretaceous-Tertiary shortening, basin development, and volcanism in central Tibet. Geol. Soc. Am. Bull. 2005, 117, 864-878. [CrossRef]

90. Pullen, A.; Kapp, P.; Gehrels, G.E.; Ding, L.; Zhang, Q.H. Metamorphic rocks in central Tibet: Lateral variations and implications for crustal structure. Geol. Soc. Am. Bull. 2011, 123, 585-600. [CrossRef]

91. Fan, J.J.; Li, C.; Xie, C.M.; Wang, M.; Chen, J.W. The evolution of the Bangong-Nujiang Neo-Tethys ocean: Evidence from zircon $\mathrm{U}-\mathrm{Pb}$ and $\mathrm{Lu}-\mathrm{Hf}$ isotopic analyses of Early Cretaceous oceanic islands and ophiolites. Tectonophysics 2015, 655, 27-40. [CrossRef]

92. Hao, L.L.; Wang, Q.; Wyman, D.A.; Ou, Q.; Dan, W.; Jiang, Z.Q.; Yang, J.H.; Li, J.; Long, X.P. Andesitic crustal growth via mélange partial melting: Evidence from Early Cretaceous arc dioritic/andesitic rocks in southern Qiangtang, central Tibet. Geochem. Geophys. Geosyst. 2016, 17, 1641-1659. [CrossRef]

93. He, H.Y.; Li, Y.L.; Wang, C.S.; Zhou, A.; Qian, X.Y.; Zhang, J.W.; Du, L.T.; Bi, W.J. Late Cretaceous (ca. 95 Ma) magnesian andesites in the Biluoco area, southern Qiangtang subterrane, central Tibet: Petrogenetic and tectonic implications. Lithos 2018, 302, 389-404. [CrossRef]

94. Li, S.M.; Wang, Q.; Zhu, D.C.; Stern, R.J.; Cawood, P.A.; Sui, Q.L.; Zhao, Z. One or two Early Cretaceous arc systems in the Lhasa Terrane, southern Tibet. J. Geophys. Res. Solid Earth 2018, 123, 3391-3413. [CrossRef]

95. Liu, D.L.; Huang, Q.S.; Fan, S.Q.; Zhang, L.Y.; Shi, R.D.; Ding, L. Subduction of the Bangong-Nujiang Ocean: Constraints from granites in the Bangong Co area, Tibet. Geol. J. 2014, 49, 188-206. [CrossRef]

96. Liu, D.L.; Shi, R.D.; Ding, L.; Zou, H.B. Late Cretaceous transition from subduction to collision along the Bangong-Nujiang Tethys: New volcanic constraints from central Tibet. Lithos 2018, 296, 452-470. [CrossRef]

97. Wang, Q.; Zhu, D.C.; Zhao, Z.D.; Liu, S.A.; Chung, S.L.; Li, S.M.; Liu, D.; Dai, J.G.; Wang, L.Q.; Mo, X.X. Origin of the ca. 90 Ma magnesia-rich volcanic rocks in SE Nyima, central Tibet: Products of lithospheric delamination beneath the Lhasa-Qiangtang collision zone. Lithos 2014, 198, 24-37. [CrossRef]

98. Fan, J.J.; Li, C.; Xie, C.M.; Wang, M. Petrology, geochemistry, and geochronology of the Zhonggang ocean island, northern Tibet: Implications for the evolution of the Banggongco-Nujiang oceanic arm of the Neo-Tethys. Int. Geol. Rev. 2014, 56, 1504-1520. [CrossRef] 